\title{
Reconceptualising the co-evolution of firms-in-industries and their environments: Developing an inter-disciplinary Triple Embeddedness Framework
}

\author{
Frank W. Geels* \\ Sustainable Consumption Institute E Manchester Institute of Innovation Research, University of Manchester, Harold Hankins building room 6.01, Oxford \\ Road, Manchester M13 9PL, United Kingdom
}

\section{A R T I C L E I N F O}

\section{Article history:}

Received 26 March 2010

Received in revised form

26 September 2013

Accepted 20 October 2013

Available online 16 November 2013

\section{Keywords:}

Co-evolution

Grand societal challenges

Incumbent firms

Embeddedness

Appreciative theorising

\begin{abstract}
A B S T R A C T
This inter-disciplinary theory-building paper is motivated by the debate on grand societal challenges and by calls in the innovation studies literature for frameworks that offer a better understanding of the co-evolution of industries and their economic, political, cultural, and social environments. In response to these debates, the paper develops a new triple embeddedness framework (TEF), which conceptualizes firms-in-industries as embedded in two external (economic and socio-political) environments and in an industry regime which mediates strategic actions towards the external environments. The TEF's theoretical logic draws on the adaptation-selection debate, which suggests that the co-evolution phenomenon can be approached from two angles. With regard to (population-level) selection theories, which highlight pressures on industries from external environments, the TEF accommodates insights from evolutionary economics, neo-institutional theory, and economic sociology. With regard to (firm-level) adaptation theories, the TEF accommodates insights from externally-oriented strategy schools (economic positioning strategy, innovation strategy, corporate political strategy, discursive strategy, issue management) and internally-oriented strategy approaches (linked to knowledge/capabilities and cognition/sensemaking). The combination of insights produces a multi-dimensional framework with bi-directional interactions between firms-in-industries and their environments. Implications for the grand challenge agenda are discussed in a separate section and illustrated with examples.
\end{abstract}

(c) 2013 Elsevier B.V. All rights reserved.

\section{Introduction}

This conceptual paper aims to develop a new framework to understand the co-evolution and bi-directional interactions between industries and their environments. The first motivation for this attempt is that new substantive topics have appeared on the agenda of innovation studies such as 'grand societal challenges' and socio-technical transitions. The Europe 2020 Strategy suggests that these grand challenges include climate change, energy security, transport and resource efficiency, food safety, obesity, and environmentally friendly production. Many of the 'grand challenges' are negative externalities for incumbent firms in industries such as oil, coal, automobiles, electric utilities, gas, and agro-food. Firms in these industries are large, politically powerful, and scaleintensive with many sunk investments. These incumbent firms also possess many 'complementary assets', such as specialized manufacturing capability, experience with large-scale test trials, access

\footnotetext{
* Tel.: +44 1612757374

E-mail address: frank.geels@mbs.ack
}

to distribution channels, service networks, or complementary technologies, which gives them strong positions vis-à-vis new entrants (Rothaermel, 2001).

On the one hand, large incumbent firms can play a role in addressing grand challenges, by developing and marketing (radical) technical innovations. On the other hand, incumbent firms tend to be reluctant to develop radical solutions for various reasons: (a) they are locked in and have sunk investments in existing technologies, skills and people (Arthur, 1989; Unruh, 2000; Walker, 2000), (b) radical innovations are risky and may disrupt existing competencies (Tushman and Anderson, 1986), (c) firms have limited direct incentives to address societal problems because of collective good issues and free rider problems. Incumbent firms therefore prefer incremental change and the continuation of existing (innovation) trajectories.

These considerations imply that the reorientation of incumbent industries towards radical innovations that address grand challenges will require pressures from consumers, policymakers, civil society, and social movements. The accumulation of such pressures may stimulate incumbent firms to overcome lock-in mechanisms and reorient towards more radical innovations. 
The specific problem that motivates this paper is that dominant frameworks in innovation studies (e.g. evolutionary economics, innovation systems) are not well suited to address the issues, discussed above. Evaluating progress in innovation studies, Morlacchi and Martin (2009: p. 575) remark that: "we still don't have a very satisfactory theory of social change. Our ability to improve social problems remains rather limited, and we do not know why we appear to have only modest gains in relation to many societal problems". In my view, this problem is, amongst others, due to a limited conceptualization of industry environments, which pays little attention to civil society, public opinion, cultural discourse, and social movements. So, to address the new challenge-led agenda, I suggest that a new conceptual framework is needed which accommodates interactions between incumbent firms-in-industries and a broader set of environments (which also includes the economic environment).

The second motivation is that various scholars have suggested that a broad approach to co-evolution is an important conceptual challenge for innovation studies, but that this has not yet resulted in concrete frameworks. Dosi (2000: p. 365), for instance suggests that: "A first [important issue on the research agenda] concerns co-evolutionary processes. (...) Co-evolution (...) is a broad area covering, for example, the interactions between the forms of economic organization, social and political institutions and technical change." Dosi and Marengo (2007: p. 491) further suggest that: "(...) evolutionary theory should coherently embrace an "embeddedness' view of organizations, whereby the latter are not simply efficient solutions to informational problems arising from contract incompleteness and uncertainty, but also shape the 'visions of the world', interaction networks, behavioral patterns, and the identity of agents".

Innovation scholars have, of course, addressed co-evolution with regard to 'upstream' interactions between industry, universities and policymakers (e.g. Nelson, 1994; Von Tunzelman, 2003). But it is fair to say that innovation scholars have paid far less attention to the co-evolution between industry and wider environments such as civil society, social movements, culture, and politics. Pettigrew (2012) suggests that business and society relations are also under-studied in the context of wider organization theory: "One big challenge is business and society relationships. (...) Regrettably thus far much of the research literature on business and society relationships has been confined by the value laden language of corporate social responsibility. A more inclusive, neutral, and social-science based agenda would look the power, legitimacy, responsibility, governance, and regulation of the modern corporation. In that intellectual space there are many big questions about the leadership, change, and performance of the modern corporation in its institutional field and its relationships with the State which have barely been addressed" (p. 1325).

To some extent, developing such a broad approach to coevolution aims to revive Schumpeter's broad agenda, which tried to develop an economic sociology that "includes not only actions and motives and propensities but also the social institutions that are relevant to economic behaviour such as government, property, contract, and so on" (Schumpeter, 1954: p. 21). Several scholars (Hodgson, 1993; Andersen, 2009) have noted that Schumpeter's broad agenda has been lost in (neo-Schumpeterian) evolutionary economics, which tends to focus more narrowly on firms, bounded rationality, search routines, innovation, knowledge, capabilities, and market selection. Scholars like Chris Freeman, however, kept the broad agenda alive and argued for "the need for reintegrating economic theory with the other social sciences" and "the need to reconstitute 'political economy' with a full recognition of the role of institutions and institutional change" (Freeman, 1988: p. 12).

So, the second motivation is to contribute to conceptual renewal and expansion in innovation studies by developing a broad approach to co-evolution of industries and their environments. This approach should not just be broad, but also conceptualise specific mechanisms of co-evolution to address Malerba's (2006: p. 18) suggestion: "The challenge for research here is to go to a much finer analysis at both empirical and theoretical levels, and to move from the statement that everything is coevolving with everything else to the identification of what is coevolving with what, how intense is this process and whether indeed there is a bi-direction of causality".

This paper conceptualizes industry as a population of firms in a sector, which produce similar goods and services. On the one hand, one can refer to an industry as a collective entity, because firms in a population share certain characteristics and face similar pressures from their environments. On the other hand, firms are the concrete actors doing the acting, which is why the paper uses the term 'firms-in-an-industry'. Implicit in this term is a tension between, on the one hand, pressures towards similarity and isomorphism (from selection environments and 'industry regimes') and, on the other hand, firm-level actions causing divergence and variation. In organization theory, this tension underlies the longstanding adaptation-selection debate between different views on how organizations and environments co-evolve (Astley and Van de Ven, 1983; Levinthal, 1991; Lewin and Volberba, 2003). Lewin and Volberda (1999) suggest that selection theories and adaptation theories represent two levels of analyses, with the former emphasizing selection pressures that populations face from their environments, and the latter emphasizing (differences in) firmlevel strategies, capabilities and perceptions. They also suggest that: "single-theme explanations for the adaptation-selection phenomenon have reached their limit. Progress in the field requires combining and recombining multiple lenses instead of increasing fragmentation. We should consider the joint outcomes of managerial adaptation and environmental selection" (p. 523).

The theorising strategy in this paper has two characteristics. Firstly, the paper practices the style of appreciative theorising, which Nelson and Winter (1982: p. 46) characterise as developing a way of looking at phenomena, a framework of appreciation that describes variables and their relationships and gives a language for discussing these. So, the paper aims to develop a conceptual framework which can be used to guide empirical research. Porter (1991: p. 98) provides a useful epistemological clarification: “A framework (...) encompasses many variables and seeks to capture much of the complexity (...). Frameworks identify the relevant variables and the questions which the user must answer to order to develop conclusions tailored to particular industry and company. (...) In addition, all the interactions among the variables in the frameworks cannot be rigorously drawn. The frameworks, however, seek to help the analyst to better think through the problem." Secondly, to develop a new framework of the co-evolution of industries and their environments the paper mobilizes and combines insights from various social science literatures (as suggested by Freeman). The selection and discussion of literatures is based on Lewin and Volberda's suggestion that different theories approach co-evolutionary interactions from different angles. With regard to population-level selection theories, the framework uses insights from evolutionary economics and neo-institutional theory, which distinguish different kinds of environmental pressures on populations of firms. The discussion is complemented with insights from economic sociology, which advanced the notion of 'embeddednesss' to capture how economic entities are shaped by wider political, social and cultural contexts. With regard to firm-level adaptation theories, the paper uses insights from both externally-oriented strategy approaches (economic positioning, corporate political strategy, discursive strategy, and issue management), which address how firms aim to shape environments, and internally-oriented strategy schools (knowledge/skills/capabilities and cognition/sensemaking), which address how firms adapt to 
external pressures by changing their capabilities, beliefs and identities.

The paper is structured as follows. Section 2 discusses how evolutionary economics, neo-institutional theory, and economic sociology conceptualize the co-evolution of industries and their environments. It subsequently combines relevant insights to develop the structural backbones of the new Triple Embeddedness Framework (TEF), which conceptualizes firms-in-industries as embedded in two kinds of external environments (economic task environment and a socio-political environment) and in an 'industry regime' which mediates perceptions and actions towards both environments. Section 3 makes the TEF more dynamic by discussing various (externally- and internally-oriented) firm-level strategies. This discussion addresses how firms-in-industries adapt by trying to shape the various environments and by changing elements of industry regimes, which constitutes industry reorientation. Section 4 discusses some implications of the TEF for the new agenda of grand societal challenges. The paper ends in Section 5 with concluding comments.

\section{Developing the structural backbones of the triple embeddedness framework}

This section first discusses how evolutionary economics, neoinstitutional theory, and economic sociology conceptualize the co-evolution of firms-in-industries with their environments. Each of these three fields approaches this topic from the angle of wider environments which exert influences on firms-in-industries. They differ, however, in terms of conceptual focus, with evolutionary economics highlighting 'material' aspects (markets, resources, competition) and the other two fields emphasizing 'idealist' aspects (meanings, beliefs, norms). Insights from different fields may therefore possibly complement each other. Sections $2.1-2.3$ do not aim to portray the three fields in their entirety, but focus on the main ideas and mechanisms with regard to interactions between firms-inindustries and their environments. Each section contains a stylized representation of main ideas, followed by an evaluation of strengths for the paper's topic and a discussion of on-going tensions and debates in each field. Section 2.4 then combines some of the insights from the different literatures to develop the structural backbones of the new triple embeddedness framework.

\subsection{Evolutionary economics}

Evolutionary economics conceptualizes markets as primary environments which exert selection pressures on firms-inindustries which compete for scarce resources. Firms adapt to this selection pressure through innovation, which is seen as the core dimension of industry-internal competition (Dosi, 2000). Firms offering products with a better fit with the selection environment receive more resources, which enable them to reproduce their routines and capabilities. Firms with lower fitness receive fewer resources and may (ultimately) die.

In terms of micro-assumptions, evolutionary economics is based on the behavioural theory of the firm (Cyert and March, 1963; Nelson and Winter, 1982), which assumes that firms have limited foresight, are boundedly rational, and use routines, rules of thumb, and standard-operating procedures for decision-making. Firms 'satisfice' rather than 'optimize', which means that firms stick to behavioural rules and routines as long as this leads to satisfactory outcomes. When performance falls below aspiration levels, search rules are activated which lead to search activities (under bounded rationality) for better adapted routines.

Evolutionary economics also draws on the capability- and knowledge-based view of the firm (Grant, 1996; Dosi and Grazzi,
2006). Innovation is seen to derive from search and learning activities (operationalized as R\&D) in a technological knowledge space. These search activities are routine-based (guided by search heuristics) and tend to be local and incremental, staying close to existing routines and capabilities. The search processes result in variations (such as product innovations) to which markets provide 'performance feedback' (Greve, 2003), selecting the variations with the highest fit. The overall process can therefore be characterized as trial-and-error (or behavioural) learning, with firms retaining the innovations (and associated routines) that markets select.

Because of these characteristics, evolutionary economics accounts for both variety and similarity. On the one hand, there is persistent heterogeneity between firms-in-industries, which differ in terms of specific capabilities, organizational routines, and search heuristics (Dosi, 2000). This heterogeneity is continuously refreshed through search and innovation activities. On the other hand, firms-in-industries become similar (to some degree), because selection pressure rewards only some innovations and because successful routines spread through a population through differential growth of the successful firm and through imitation (Nelson and Winter, 1982). Firms-in-industries therefore share many routines and capabilities which cluster into technological regimes that provide templates for technology-developers, guiding and focusing their activities in certain directions rather than others. Existing technical trajectories tend to be path-dependent and locked-in, because "once a path has been selected and established, it shows a momentum of its own" (Dosi, 1982: p. 153).

Interaction between industry and environment is mainly onedirectional in evolutionary economics, which sees firms as adaptive entities that adjust to pressures from an independent selection environment. This adaptation (through routine-based search and learning activities) is mediated by technological regimes, which provide constraining influences. Firms tend to resist substantial adjustments that disrupt existing routines and capabilities (Tushman and Anderson, 1986).

\subsubsection{Evaluation and on-going debates}

Evolutionary economics offers several relevant insights for this paper's topic. Firstly, the dynamic notion of trajectories provides a useful way to conceptualise reorientation, namely as a change in the directionality of innovation. Secondly, the notion of technological regime helps understand why substantial reorientation of incumbent industries is difficult (because of lock-in and path dependence). Thirdly, the notion of technological regimes suggests that agency is shaped and mediated by wider structures, which provides a linkage point to institutional theories.

There are also some on-going debates in evolutionary economics about under-developed aspects. First, it has been argued that evolutionary economics pays too little attention to the beliefs, cognitions and interpretations of actors. Gavetti and Levinthal (2004: p. 1314) suggest that this is due to the heritage of behavioural theory: "Much theorizing within the tradition of the behavioural theory of the firm (...) is relatively silent on the issue of how alternatives are to be evaluated or issues of cognition more generally. The result is a view in which deliberation and strategic choice are relegated to a modest corner." This lack of attention relates to the scepticism in evolutionary economics about foresight and people's ability to foresee the future. This scepticism led to ideas of 'blind' (Darwinian) variation. Others (e.g. Nelson, 2008) have, however, argued that the lack of correctness about the future does not mean that actors do not have beliefs or make plans. They therefore see variation as Lamarckian and guided by cognitive maps, beliefs and intentions (Schot and Geels, 2007). North (2005) further argues that interpretations and beliefs are crucial to understand economic change: "In contrast to Darwinian evolutionary theory, the key to human evolutionary change is the intentionality of the players. (...) Human evolution 
is guided by the perceptions of the players. (...) Economic change, therefore, is for the most part a deliberate process shaped by the perceptions of the actors about the consequences of their actions" (North, 2005: p. viii).

A second concern is that the emphasis on routines downplays intentionality and strategy. Gavetti and Levinthal (2004: p. 1314), for instance, complain that: "The image of organizational action as largely driven by routines seems to negate the role of strategic choice". Fagerberg (2003) and Child (1997) formulated similar criticisms. This lack of intentional strategy is particularly problematic in capital-intensive sectors, like the ones mentioned in the introduction, where firms tend to adopt a strategic planning style, in which corporate headquarters play a "central role in deciding technological priorities and showing 'strategic intent"' (Tidd et al., 2005: p. 225).

The third debate is about how to conceptualise other environments than markets. I would argue that evolutionary economics does not really address civil society, public opinion, cultural discourse, and social movements. But it does acknowledge policies and regulations. Dosi (1982), for instance, conceptualized public policies as 'focusing devices' which shape markets (taxes, subsidies, regulations) and innovation activities (technology programs, R\&D policies, intellectual property rights). Nelson (1994) and Von Tunzelman (2003) also emphasized that governance institutions co-evolve with technology and industry structure. The role of institutions has also been elaborated in the national innovation system approach (Lundvall, 1992; Nelson, 1993), which has however lost some of the dynamic characteristics of evolutionary economics. Nevertheless, I think it is fair to say that the political dimension of policy has remained under-developed in evolutionary economics and innovation system theories (Flanagan et al., 2011). I also agree with Fagerberg (2003: p. 127) who suggests that there has been little interaction between evolutionary economics and neoinstitutional theory. Recent papers have therefore tried to better conceptualise the role of institutions in evolutionary economics, with Nelson (2002) proposing to see institutions as 'social technologies' and 'modes of governance' which provide low transaction cost ways of getting something done, and Pelikan (2003) developing the view that institutions are constraints reducing the choice set to agents. Both attempts, however, are limited if compared to neo-institutional theory, which will be discussed next.

A fourth concern is that the emphasis on adaptation to selection pressures may assume a too passive view of firms, which is especially problematic for firms in large and politically powerful industries (such as oil, automobiles, electricity, agro-food) which actively shape environments (Schot and Geels, 2007).

\subsection{Neo-institutional theory}

Neo-institutional theory, which emerged in the 1980s when a broader cognitive turn swept through the social sciences, is also a selection theory (Lewin and Volberba, 2003), because of its emphasis on isomorphic pressures that institutions exert on organizations. Neo-institutional theory conceptualises firms as operating in an organizational field, which DiMaggio and Powell (1983: p. 148) define as "those organizations that, in the aggregate, constitute a recognized area of institutional life: key suppliers, resource and product consumers, regulatory agencies, and other organizations that produce similar services or products." Scott (1995: p. 207) further proposed that industries form the central populations, arguing that the notion of organizational fields "builds on the more conventional concept of industry, a population of organizations (...). But added to this focal population are those other and different organizations that critically influence their performance."

Neo-institutional theory emphasizes the influences from the institutional environment, which affect firms-in-an-industry in non-commercial ways. "In institutional environments, organizations compete for social fitness rather than economic efficiency" (Powell, 1991: p. 184). The selection criterion for social fitness is legitimacy, which Suchman (1995: p. 574) defines as follows: “Legitimacy is a generalized perception or assumption that the actions of an entity are desirable, proper, or appropriate within some socially constructed system of norms, values, beliefs and definitions". So, institutions exert selection pressure, because firms-in-an-industry are supposed to conform to them. Failure to do so may lower their legitimacy in the eyes of wider publics, social movements, and policymakers, which may not only damage public acceptance ('license to operate') and government protection, but also access to external capital (Lounsbury and Glynn, 2001).

DiMaggio and Powell (1983) distinguished three kinds of institutional pressures to which firms-in-industries conform: (a) coercive isomorphism, exerted amongst others by government mandates and regulations, (b) normative pressures, exerted by professional standards and expectations regarding appropriate behaviour, and (c) mimetic processes, by which firms model themselves after similar organizations that they perceive to be more legitimate or successful. Scott (1995) further elaborated and systematized these ideas, distinguishing three institutional pillars with different logics and mechanisms (Table 1 ): (a) regulative institutions (explicit rules, laws, regulations) emphasize constraints on action, assume an instrumental logic (based on rewards and punishments), and are often the focus of institutional economists (e.g. North, 1990), (b) normative institutions (values, norms, role expectations, duties) assume a logic of appropriateness, and are often the focus of classical sociologists (e.g. Parsons, 1937), (c) cultural-cognitive institutions (models of reality, cultural categories, classifications, mental maps, belief systems) constitute the nature of social reality and the frames through which meaning is made. These cultural-cognitive institutions are theorised and investigated by neo-institutional scholars (e.g. Zucker, 1987; Powell and DiMaggio, 1991) who draw on ideas from social constructivism and structural anthropology. Cultural-cognitive institutions are seen as deep and foundational, because they, firstly, constitute beliefs, identity, preferences and interests (human beings are assumed to be malleable), and, secondly, because they are taken-for-granted, which means that actors are usually unaware of their foundational beliefs.

Because of these two reasons, Scott (2008: p. 429) argues that cultural-cognitive institutions provide "the deeper foundations of institutional forms. (...) Although regulative features are more visible, they can also be more superficial, 'thinner' and less consequential than normative and cultural elements". This difference is visible in Scott et al.'s (2000) distinction between 'institutional logics' (the cultural beliefs, values and ideas shared by members of an organizational field, which constitute endogenous organizing principles) and a 'governance system' (the arrangements which support the regularized control over the activities within a field).

Interactions are mainly one-directional in the sense that (various) institutions exert pressures to which firms-in-industries conform.

\subsubsection{Evaluation and on-going debates}

For this paper institutional theory has several strengths. First, the notion of organizational fields offers a wider view of industry environments, which includes civil society, public opinion, and policymakers. Second, the understanding of institutions is multidimensional and encompasses different causal mechanisms.

There are also some on-going debates in neo-institutional theory about under-developed aspects. First, neo-institutional theory has been criticized for deterministic (one-directional) causality in which passive actors ('cultural dopes') simply conform to isomorphic institutional pressures. To introduce more strategic agency 
Table 1

Three pillars of institutions (Scott, 2001: p. 52).

\begin{tabular}{|c|c|c|c|}
\hline & Regulative & Normative & Cognitive \\
\hline Basis of compliance & Expedience & Social obligation & Taken for grantedness, shared understanding \\
\hline Basis of order & Regulative rules & Binding expectations & Constitutive schema \\
\hline Mechanisms & Coercive (force, punishments) & Normative pressure (social sanctions such as 'shaming') & Mimetic (learning, imitation) \\
\hline Logic & Instrumentality & Appropriateness & Orthodoxy \\
\hline Indicators & Rules, laws, sanctions & Certification, accreditation & Common beliefs, shared logics of action \\
\hline Basis of legitimacy & Legally sanctioned & Morally governed & Comprehensible, recognizable, culturally supported \\
\hline
\end{tabular}

and bi-directional interactions, scholars began emphasizing that firms-in-industries not only adapt to institutional pressures, but also respond strategically to shape them (Greenwood and Hinings, 1996). Oliver (1991), for instance, distinguished several strategies: acquiescence, compromise, avoidance, defiance, and manipulation. These strategic actions have been further elaborated and refined in the literature on 'institutional entrepreneurship' (Garud et al., 2007).

Second, neo-institutional theory has been criticized for an overly homogeneous and monolithic view of organizational fields, which neglects the role of power and position. Scholars therefore started developing more differentiated views, arguing that the strength of institutional logics may vary in organizational fields. For both peripheral actors (Leblebici et al., 1991) and central actors (Greenwood and Suddaby, 2006) this strength may be less, giving them more scope for strategic action than actors in the middle (Aldrich, 2010): peripheral actors find it easier to deviate from institutional logics, while central actors can use power to shape institutions to their advantage.

Thirdly, neo-institutional theory has been criticized for being better in explaining stability (conformity) than change (Greenwood and Hinings, 1996). Scott (2008), however, argues that recent conceptualizations are better in addressing change, because they incorporate strategic behavior and use of power by actors that aim to shape institutions.

Fourthly, the emphasis in neo-institutional theory on institutions and legitimacy may lead to some neglect of competition in material environments. This problem was not present, however, in early formulations such as DiMaggio and Powell (1983) who recognized both economic selection pressures and institutional isomorphic pressures, acknowledging that organizations compete "for social as well as economic fitness" (p. 150). Also Scott et al. (2000) suggest that organizations operate in both socio-political environments and material-resource environments (demand-side factors, supply side factors, technologies, industry structures).

\subsection{Economic sociology}

New economic sociology, which emerged in the mid-1980s, aims to show that the economy is not a separate domain with its own logics, but is instead enmeshed with social, political, and cultural dynamics. Economic sociology has embraced 'embeddedness' as programmatic notion (Krippner, 2001), which will be discussed in more detail because of its relevance for the paper's interest in industry environments. Although economic sociology practices a 'shaping logic' rather than a 'selection logic', it emphasizes, like evolutionary economics and neo-institutional theory, the influences from broader environments on the economy, markets and firms.

Polanyi (1944) first introduced the notion of embeddedness, showing that markets were embedded in society until the early 19th century, when politics, regulation and ideology contributed to the (incomplete) dis-embedding of markets. New economic sociologists distinguish different kinds of embeddedness. Granovetter (1985) highlighted ('horizontal') embeddedness of economic transactions in social networks and the role of trust and personal ties. Zukin and DiMaggio (1990) further distinguished cognitive embeddedness ("regularities of mental processes"), cultural embeddedness (collective understandings, beliefs, ideologies, norms), and political embeddedness (legal framework, tax codes, policies).

The notion of cognitive embeddedness assumes that people always make sense of the world and that the human mind is programmed to develop categories, mental maps, and cognitive schemas (Dobbin, 2004). These categories, maps and schemas are (in large parts) social and shared with others (an idea that has overlaps with neo-institutional theory). Sociologists therefore argue that the human mind is society writ small (Douglas, 1986). Core aspects of the psyche are situational rather than hard-wired, which implies that definitions of preferences and perceptions of interests are variable rather than given. At the industry-level shared maps or schemas can give rise to industry mindsets (Phillips, 1994).

Cultural embeddedness is the broader component of cognitive embeddedness. On a macro-level, culture constitutes capitalist 'market societies' by providing ideas and repertoires that legitimate policies and actions. Polanyi (1944), for instance, described 'free markets' (and the notion of land and labour as 'commodities') as an ideology that underpinned specific laws in the early 19 th century. On the level of specific industries, cultural discourses can provide (or undermine) legitimacy, which influences private investment and government support (Geels and Verhees, 2011). The metaphor of 'natural monopoly', for instance, underpinned regulations that protected utilities from competition for much of the 20th century (DiLorenzo, 1996).

Political embeddedness concerns relations between state and economy. A core notion is that economies and markets are underpinned by government regulations and institutions. Polanyi (1944: p. 146) already argued that: "The road to the free markets was opened and kept open by an enormous increase in continuous, centrally organized and controlled interventionism." Governments constitute markets in a foundational sense (Fligstein, 1996) by establishing property rights, rules of exchange (obligations of contracts), and governance structures (establishing legal and illegal forms of corporate behavior). Governments also shape specific industries through tariff protection, loans, cash grants, government purchases, patents, tax concessions, information and research services. Lindblom (2001: p. 42) therefore proposes that: "If the market system is a dance, the state provides the dance floor and the orchestra."

Economic sociologists accommodate some bi-directionality by acknowledging that firms and industries use power and politics to shape formal institutions to their advantage. Marx already suggested that the state is not neutral, but often colludes with economic interests instead of acting for the common good. Lindblom (2001) argues that market elites and governmental elites often cooperate and that their voices are louder than those of labor unions, consumer groups and environmental groups. He also argues that "corporations exercise political power beyond the capacity of ordinary citizens. Their power in government not only broadly distorts democracy, it also enables them to extract from the state a great variety of benefits, often at great costs to everyone else" (p. 63). Fligstein (1996: p. 662), too, suggests that "laws and accepted 


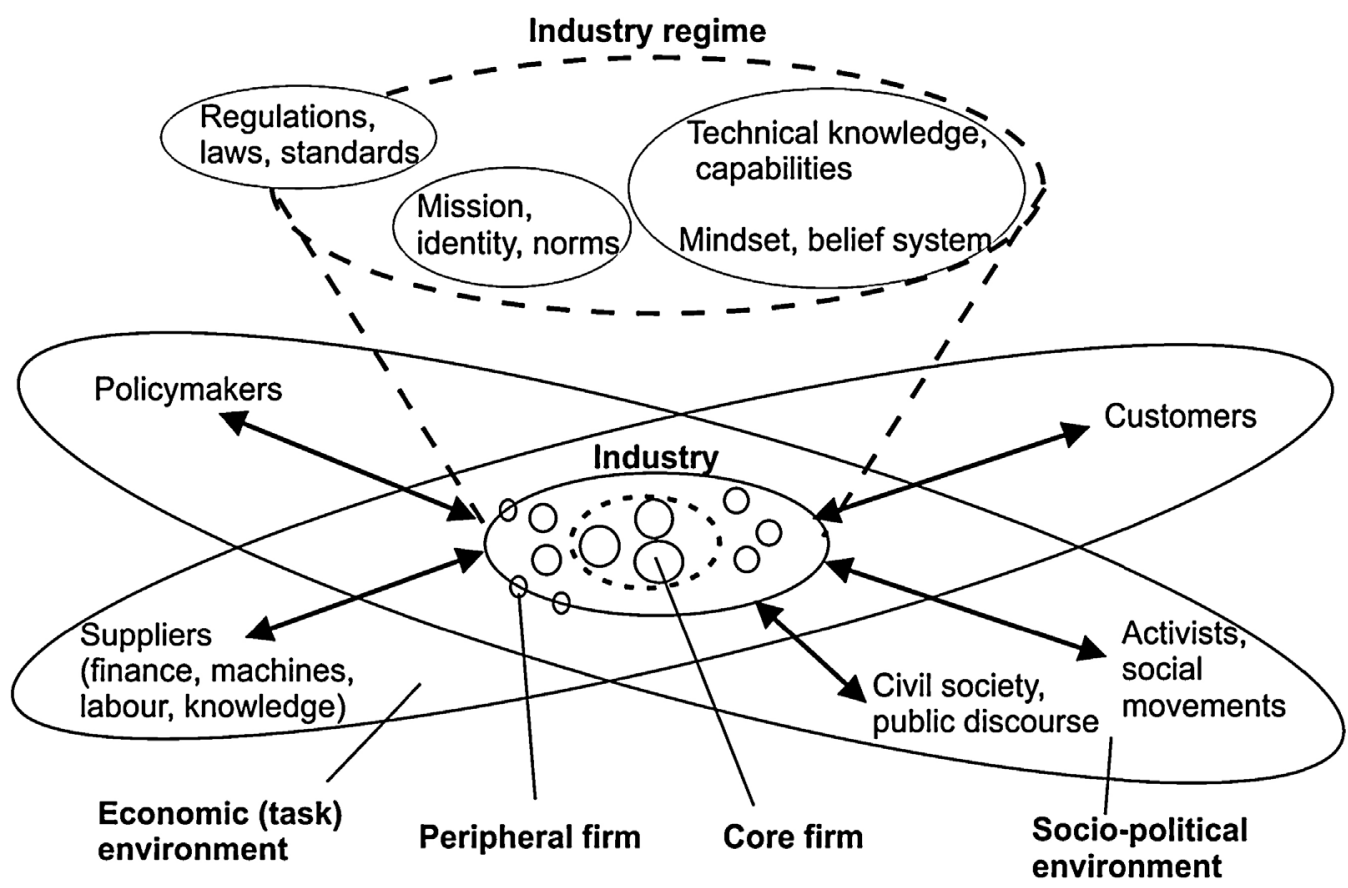

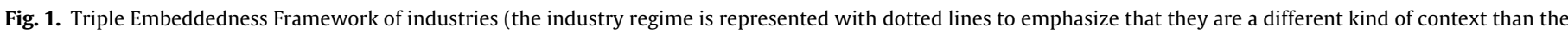
two external environments).

practices often reflect the interests of the most organized forces in society".

\subsubsection{Evaluation and on-going debates}

For this paper, economic sociology has several strengths. Firstly, it uses a multi-dimensional approach to economic entities, which accommodates social, cultural and political environments. Secondly, it acknowledges the possibility that firms-in-industries actively shape their environments to suit their interests.

There are also some on-going debates in economic sociology about under-developed aspects. First, it does not offer an operational framework or concrete model, but tends to highlight general principles. While embeddedness seems a fruitful notion, more work is needed to develop these principles into more concrete mechanisms. In a symposium on embeddedness (Krippner et al., 2004), Fred Block suggested that the task was to develop a "thicker concept of embeddedness" (p. 117), which should be made dynamic rather than static and in which "markets are always politically embedded" (p. 118). Second, the emphasis on sociological principles should not lead to a neglect of material processes (competition, resources, technology). Phrased differently, I would suggest that the emphasis on how markets are embedded and shaped by broader environments should not lead an evaporation of attention for market selection pressures.

\subsection{A triple embeddedness framework of industries in context}

This section develops the new triple embeddedness framework (TEF) by combining ideas from the three different fields in the following ways. Firstly, from evolutionary economics and neo-institutional theory, the TEF adopts the notion of selection pressures exerted simultaneously on firms-in-industries by institutional environments and economic (task) environments (Oliver, 1997; Scott et al., 2000). In the economic (task) environment, which accommodates consumers and suppliers, selection criteria include economic competitiveness, efficiency, and financial performance. In the institutional environment, selection criteria include legitimacy and social fitness.
Secondly, to unpack pressures from the institutional environment, institutions are conceptualised as nested and existing at various levels (Scott, 1995). Rao (1997: p. 1613) suggest that specific institutions exist at the industry-level ("particular regulations, norms, and ideas that structure the actions of individuals and groups") and general institutions at the societal level ("broadly accepted norms, values and belief systems that constitute the master principles of society"). Likewise, Robertson and Langlois (1994: p. 362) distinguish between endogenous institutions ("specific to a particular firm or industry") and exogenous institutions ("features of the economy or society at large"). I propose that 'general' or 'exogenous' institutions exert selection pressures on firms-in-industries through the activities of actors in a socio-political environment (e.g. social movements, wider publics, media, policymakers). The underlying idea is that a mis-match between 'general' institutions (broadly accepted norms, values, belief systems) and industry-specific institutions does not by itself generate tension or pressure on firms-in-industries, but through the activities (complaints, demands, criticisms) of socio-political actors.

Thirdly, I propose that 'specific' or 'endogenous' institutions influence firms-in-industries in a different way, acting as structures that mediate actions and perceptions. These 'specific' or 'endogenous' institutions will be conceptualised below as 'industry regimes'.

Fourthly, building on recent debates in evolutionary economics and neo-institutional theory, the interactions between firms-inindustries and their economic and socio-political environments are conceptualised as bi-directional.

Fifthly, building on recent debates in neo-institutional theory, firms-in-industries are distinguished into three types: core firms (which have power to discipline other firms and shape regime rules to suit their interests), firms 'in the middle', and peripheral firms (fringe actors or new entrants for whom it is relatively easier to deviate from regime rules).

Sixthly, the Triple Embeddedness Framework (TEF) of industries (Fig. 1) builds on embeddedness-concept from economic sociology, but further develops it by distinguishing different kinds of 
embeddedness and relations. Interactions between firms-inindustries and social groups in economic and socio-political environments can be regarded as 'horizontal' embeddedness, while relations between incumbent firms and industry regimes can be seen as 'vertical embeddedness'. In terms of Giddens's structuration theory, the former refers to industry actors acting in social systems (social networks and interactions), whereas the latter refers to actors drawing on social structures (rules, resources, institutions). Systems and structures thus provide two types of contexts for actors:

Social systems are systems of social interaction; as such they involve the situated activities of human subjects. (...) Systems, in this terminology, have structures, or more accurately structural properties; they are not structures in themselves. (...) To study the structuration of a social system is to study the ways in which that system, via the application of generative rules and resources, and in the context of unintended outcomes, is produced and reproduced in interaction. (Giddens, 1979: p. 65-66)

Building on these notions, the 'Triple Embeddedness Framework' (TEF) aims to accommodate the view that firms-in-industries are embedded (horizontally) in two external environments and are shaped (vertically) by industry regimes. The concept of industry regime, and associated issues of lock-in and deviation, are further discussed below.

\subsubsection{Industry regime}

The idea that actions are mediated by a regime stems from evolutionary economics (Section 3.1). But because the notion of 'technological regime' has increasingly been operationalized in terms of technical knowledge and capabilities, I suggest that a broader conceptualization is needed which uses insights from neoinstitutional theory. Scott's (2001) view that agency is mediated by cultural-cognitive, normative, and formal-regulative institutions (Scott, 1995) seems particularly useful. ${ }^{1}$ To accommodate this broader understanding, the TEF proposes the concept of 'industry regime', which are industry-specific institutions that mediate perceptions and actions of firms-in-an-industry towards external environments. To accommodate the evolutionary economists' emphasis on technological knowledge, I add a functional-cognitive institution to Scott's typology. Industry regimes are thus proposed to contain four types of elements: (1) technical knowledge and capabilities, which enable and constrain what firms-in-industries can do, (2) mindsets and cognitive frames, which constitute how actors perceive the nature of social reality, (3) values, identity, mission, which specify what actors see as appropriate, (4) formal regulations, laws, standards. Following Scott et al. (2000), the first three elements form 'institutional logics', which constitute endogenous organizing principles that require ongoing reproduction. The fourth element is part of a 'governance system', i.e. arrangements which support the regularized control of industry activities. Rules, regulations and standards are partly externally imposed (by policymakers) and partly internally enacted via compliance mechanisms (e.g. industry associations formulating codes of conduct). The fourth element is therefore represented in Fig. 1 as both in and outside industry regimes. The four regime elements will be briefly discussed and further embedded in relevant literatures.

1) Functional-cognitive regime elements: Technical knowledge. Technical knowledge and cognitive routines form crucial resources

\footnotetext{
1 This distinction has similarities to Giddens (1979) structuration theory, which suggests that action in social systems is mediated by three types of structures: (a) structures of signification (meaning), (b) structures of legitimization (norms), (c) structures of domination (power and regulations).
}

for operational processes. They enable and constrain functional performance and form the basis for technological trajectories (Dosi, 1982). At the industry level, shared knowledge is referred to as a technological regime.

2) Cultural-cognitive regime elements: Industry mindsets and cognitive frames. Firms-in-an-industry share cultural-cognitive categories and frames, which some scholars refer to as 'industry recipe' (Spender, 1989) or 'industry mindset' (Phillips, 1994). Cultural-cognitive institutions constitute the nature of reality, shape interpretations of (pressures and opportunities in) external environments and influence strategic choices and decisions (Daft and Weick, 1984; Hoffman and Ocasio, 2001).

3) Normative regime elements: Industry identity, values and mission. Normative institutions provide behavioural templates that specify 'the way we do things in this industry' and articulate what industry actors consider to be appropriate behaviour. These institutions include shared identity, which is what firms-inan-industry "believe to be its central, enduring, and distinctive character" (Dutton and Dukerich, 1991: p. 520). Normative institutions also fulfil external functions by signalling propriety towards relevant stakeholders. Industry mission, for instance, signals the societal purpose of an industry, which aims to confer normative legitimacy from actors in the socio-political environment (Hoffman and Ocasio, 2001).

4) Formal-regulative institutions. Regulations and policies (taxes, subsidies, intellectual property laws, tariffs, R\&D programs) shape industries by influencing markets, industrial production decisions, and innovation processes (Fligstein, 1996). These institutions are partly externally imposed by policymakers and governmental agencies. But they are also partly internally enacted by industry associations and professional organisations which articulate and implements guidelines or standards for industry members (DiMaggio and Powell, 1983).

\subsubsection{Industry regime, lock-in and path dependence}

The regime elements cluster together into semi-coherent configurations that orient firms-in-industries and provide directionality. In the industries mentioned in the introduction large incumbent firms tend to be committed to industry regime elements, which are stabilized by various lock-in mechanisms:

1) Technical knowledge and competencies represent 'cognitive capital' that actors do not want to disrupt or cannibalize (Tushman and Anderson, 1986). Core capabilities can turn into core rigidities, which prevent timely reorientation (LeonardBarton, 1992).

2) Shared mindsets and cognitive frames can contribute to cognitive inertia, blinding actors to developments outside their focus (Tripsas and Gavetti, 2000).

3) Regulatory institutions can provide incentives that facilitate actions in certain directions rather than in other directions.

4) Industry mission and identity are difficult to change because they refer to taken-for-granted beliefs that actors have about themselves and their role in society (Dutton and Dukerich, 1991).

Because of these lock-in mechanisms, firms-in-industries tend to evolve incrementally within the parameters of the existing industry regime. ${ }^{2}$ Incremental changes accumulate into stable trajectories evolving in predictable directions (Dosi, 1982).

\footnotetext{
2 The preference for incremental change does not necessarily apply to all industries. Godoe (2000), for instance, suggests that ICT-related industries are characterized by endogenous innovation and on-going disruption (which relates to the scope of technical possibilities).
} 


\subsubsection{Firm-level variety and deviation from industry regimes}

Despite lock-in mechanisms and isomorphic pressures towards similarity, industries are also characterized by persistent variety, because firms can deviate from institutional logics. As discussed in Section 2.2, the scope for deviation varies with organizational positions: deviation may be easier for peripheral actors (Leblebici et al., 1991), which are less constrained by industry-specific institutions, and for central actors (Greenwood and Suddaby, 2006), which have power to bend the rules. With regard to each regime element, deviation can create variety in industries.

1) Although firms-in-an-industry share technological regimes, they also differ in terms of specific competencies, which form the basis for innovation-based competition (Grant, 1996).

2) While firms-in-an-industry share certain cognitive frames and categories, this does not preclude cognitive variety between firms on specific issues: "it is best to think of consensus as a set of core beliefs that are shared by many individuals within a group but around which there exists 'intracultural variation"' (Porac et al., 1989: p. 405).

3) While firms-in-an-industry share a general mission, they also use branding and PR to compete in terms of reputation, because "favourable reputations may enable firms to charge premium prices, attract better applicants, enhance their access to capital markets, and attract investors" (Fombrun and Shanley, 1990: p. 233).

4) Firms-in-an-industry may deviate in the degree of compliance to similar regulatory pressure. With regard to environmental regulations, Etzion (2007: p. 646) found that "organizational responses are quite idiosyncratic even within a specific industry governed by regulation that is equally applicable to all firms".

\section{Strategic responses and reorientation}

The structural outline of Triple Embeddedness Framework (TEF), described in the previous section, has conceptualized a broad set of environments for industries and articulated various specific mechanisms through which these environments influence firms-in-industries. It has enriched innovation studies by complementing evolutionary economics with insights from neoinstitutional theory and economic sociology. The expanded regime notion ('industry regime') also provides a multi-dimensional explanation of lock-in and path dependence, while accommodating the possibility of deviation and persistent variety. But the theorybuilding endeavour is only half completed, because the discussion has so far mainly addressed the co-evolution phenomenon from an 'outside-in' perspective: from environments towards firms-inindustries. To take the bi-directional arrows in Fig. 1 seriously, this section addresses strategic responses from firms-in-industries towards environments ('inside-out'). It thus aims to elaborate the suggestions in the critical evaluations of evolutionary economics and neo-institutional theory (Sections 3.1 and 3.2), which indicated that firms-in-industries not only adapt to external pressures but also strategically attempt to shape their environments, which are thus partly enacted. This section also aims to elaborate the implications of the observation at the end of Section 2 that firms-in-industries can strategically deviate (to a degree) from the isomorphic pressures of industry regime elements. In fact, the critical evaluations of evolutionary economics and neoinstitutional theory both suggested the need (and attempts) to go beyond relatively passive view of actors (routine-based or "cultural dopes') by acknowledging deliberate strategy, intentionality, and interpretation.
Incorporating insights from the strategy field is not easy, however, because this field consists of multiple schools (Chaffee, 1985; Mintzberg et al., 1998). Recent overviews of historical developments (Hoskisson et al., 1999; Furrer et al., 2008) showed that the strategy field moved from an external orientation in the 1970s and 1980 s to an internal orientation since the 1990s.

Externally-oriented strategy schools argue that a firm's performance is a function of its (industry) environment, and that the crux of strategic advantage is to find a profitable position, which enables firms to draw rents. Porter's (1980) industrial organization approach is a prime example, which argues that firms should find and defend positions with regard to five competitive forces (related to suppliers, buyers, competitors, new entrants and substitutes). ${ }^{3}$

Internally-oriented strategy schools argue that a firm's competitive advantage is related to unique characteristics of the firm, which enable it to do things better or cheaper than other firms. One cluster of approaches centres around the resource-based view of the firm (Barney, 1991), dynamic capabilities (Teece et al. 1997), and the knowledge-based approach (Grant, 1996), which see knowledge, skills, and capabilities as valuable, rare, inimitable and non-substitutable assets. This cluster of strategy approaches can be seen as micro-complements of evolutionary economics, because they have close affinities with the behavioural theory of the firm in terms of highlighting cognitive routines, adaptive search and behavioural (trial-and-error) learning. Another cluster of approaches conceptualizes firms as 'interpretation systems' (Daft and Weick, 1984), which need to interpret their environments and make sense of possible strategic options. Highlighting the importance of mental maps (Barr, 1998), cognitive classifications (Porac et al., 1989), and attention (Hoffman and Ocasio, 2001), this school sees the interpretive and visionary abilities of firms and managers as decisive for competitive advantage. These interpretive strategy approaches can be seen as micro-complements of neo-institutional theory, because in their sensemaking activities actors draw on cultural-cognitive institutions such as categories, abstractions and typifications. "At a basic level, institutions are part of sensemaking because they shape signification (meaning-making) via interpretation and communication. (...) In this framework, institution is akin to a coherent symbolic code, while sensemaking is the practice of use the code" (Weber and Glynn, 2006: p. 1643).

The externally- and internally-oriented strategy approaches propose different ways of adaptation and achieving fit between firms and environments. Seeing the environment as a "choice landscape', the external approaches portray adaptation as manoeuvring across space to find the best position or as active attempts to shape and mould the space. Internally-oriented approaches, on the other hand, see adaptation as a strategic process of changing the firm's nature (e.g. routines, capabilities, belief systems, mission) to improve the fit with the environment.

Both approaches will be elaborated with regard to the triple embeddedness framework in the next two sections. Section 3.1 describes externally-oriented strategic responses towards various environments in the TEF. Section 3.2 elaborates internally-oriented strategies, focusing in particular on the behavioural and interpretive processes associated with strategic reorientation and substantial changes in core regime elements (knowledge, beliefs, mission). Section 3.3 relate both kinds of strategies to each other and to the TEF.

\footnotetext{
${ }^{3}$ Porter distinguishes four generic strategic positions: cost leadership (being the low-cost producers in an entire industry), differentiation (developing unique, high quality, high performance products, which justify higher prices), cost focus (offering low-cost products in a specific market segment), and differentiation focus (offering different product variations to different market segments).
} 
3.1. Strategic responses towards economic (task) and socio-political environments

Firms-in-industries can respond strategically towards various environments in the TEF.

1. With regard to the economic (task) environment and Porter's industry forces, firms-in-an-industry use economic positioning strategies such as marketing and sales, supply chain management, and operations management (Porter, 1980). Evolutionary economists also highlight innovation strategies (Dosi, 2000), with firms competing by offering improved products or doing things better, faster, more efficiently than competitors. Tidd et al. (2005) suggest that Porter's generic strategic positions can be linked to particular technology strategies (Table 2).

2 . With regard to regulations and political environments, sociologists of law suggest that firms have substantial scope for agency: "Legal formalist imagery is at best an abstract ideal and, in reality, the regulatory legal environment is often ambiguous, contested and riddled with loopholes. (...) the overall picture is one of non-compliance, subversion, and evasion" (Edelman and Suchman, 1996: p. 487). The literature on corporate political strategy (Yoffie, 1988; Luger, 2000) further suggests that firms in many industries have substantial scope to influence policymakers. Expanding on Hillman and Hitt (1999), I distinguish five kinds of corporate political strategies (CPS):

a) Information strategy. When confronted with particular problems, firms-in-industries can set up research institutes to build expertise about the problem; use this expertise to contest scientific reports about the problem; report research results to influence the (policy) framing of issues; testify as expert witnesses in policy hearings.

b) Financial incentives strategy. To influence policymakers, firms-in-industries can make contributions to politicians or political parties; pay politicians fees for speaking at conferences or offer them lucrative jobs at the end of their career; bribe officials.

c) Organized pressure strategy. Firms-in-industries can create pressure through mobilization of employees, suppliers, customers who contact their representatives; create fake grassroots organizations ('astroturf') that claim to speak on behalf of public interests; create industry associations that speak for the industry.

d) Direct lobbying strategy. Industries can hire lobbyists to work politicians; mobilize CEOs to speak with politicians and make backroom deals. CEOs of powerful industries (cars, oil, pharmaceuticals, ICT, banking) often have easy access to presidents or prime ministers to make their case (Yoffie, 1988).

e) Confrontational strategies. Industries can oppose laws through litigation; threaten policymakers with plant closures, layoffs, or relocation; refuse to implement policies.

When firms-in-an-industry face a common threat, political strategy often takes the form of collective action (Levy and Egan, 2003). With regard to climate change, for example, Kolk and Pinkse (2007: p. 221) highlight the creation of closed industry fronts, quoting a Volkswagen executive: "In order to lay the necessary political and economic foundations, it is important that the automobile industry should present a united strategic front to stakeholders and politicians alike". Fligstein and McAdam (2012: p. 14) also suggest that organizational field actors may create "political coalitions" that "serve as defenders of the status quo and are a generally conservative force during periods of conflict". Barley (2010) shows that firms-in-industries have become more politically savvy and active since the 1970s, and have created political action committees, foundations, think tanks, and industry associations to corral governments and shape public debates.

3. Firms-in-industries also aim to shape the cultural environment, which includes broad ideologies as well as public debates about specific issues. Some approaches in political economy (Blyth, 2002; Jessop, 2010) highlight the role of ideology and macrocultural discourse in establishing and maintaining the hegemony of dominant historical blocs. Jessop (2010), for instance, suggests that economic imaginaries, which comprise a specific configuration of genres, discourses and styles, give meaning and shape to the macro-economic field. Examples of economic discourses are mercantilism, liberalism, the social market economy or revolutionary syndicalism. Levy and Egan (2003: p. 810) further argue that large firms do not only dominate a field by virtue of brute economic power and governmental connections, but also via the "discursive structure of culture, ideology, and symbolism that guides behaviour and lends legitimacy to particular organizations, practices, and distributions of resources." The goal of cultural or discursive strategies is to project particular industry interests as the general interest, and to shape ideas and discourses accordingly. The underlying assumption of cultural and discursive strategies is that civil society and public debates are battlegrounds of ideas, and that dominant ideas and ideologies shape the direction of socio-economic macro-developments, as Weber argued in his 'switchmen metaphor':"Not ideas, but material and ideal interests directly govern men's conduct. Yet very frequently the 'world images' that have been created by 'ideas' have, like switchmen, determined the tracks along which action has been pushed by the dynamic of interest" (Weber, 1946: p. 280).

Firms-in-industries also aim to shape public debates and discourses with regard to industry-specific problems such as climate change, obesity, energy security, food safety, and biodiversity. Management scholars suggest that firms use framing strategies, cultural entrepreneurship (Lounsbury and Glynn, 2001), and storytelling (Zilber, 2007) to shape public discourses. Discursive framing strategies are subtle ways to protect corporate interests, because dominant discourses shape not only what is being discussed (thus setting agendas), but also how issues are discussed. With regard to specific problems, discursive strategies can aim to shape the diagnostic framing, which identifies and defines a problem, and the prognostic framing, which advances solutions to a problem (Snow and Benford, 1988). Strategies for the former include: (a) denying or downplaying the problem (e.g. tobacco industry with regard to cancer from smoking), (b) creating doubt in the public mind by attacking the science base or highlighting uncertainties ${ }^{4}$, (c) advancing certain problem definitions (e.g. climate change as 'market failure'), (d) attack the credibility of opponents (e.g. by portraying them as fringe activists or biased researchers who exaggerate findings in order to secure research funding). Discursive strategies with regard to prognostic framing include: (a) arguing that solutions are costly or technologically unfeasible; this strategy is often used to hinder debates or delay regulation ${ }^{5}$, (b) using technological

\footnotetext{
${ }^{4}$ In 1989, for instance, firms from the car, oil, aluminium and coal industry, created the Global Climate Coalition, which during the 1990s attacked the global warming science, accused the IPCC of downplaying uncertainties, sponsored climate skeptics and disseminated their views via brochures or advertisements (Levy and Egan, 2003). BP, Shell and Ford left the GCC respectively in 1997, 1998, and 1999 because they felt that ongoing climate change denial would damage their credibility and legitimacy. The GCC was disbanded in 2002.

${ }_{5}$ Automakers used this strategy in the 1960s with regard to air-pollution control devices (Penna and Geels, 2012).
} 
Table 2

Porter's generic technology strategies (Tidd et al., 2005: p. 120).

\begin{tabular}{|c|c|c|c|c|}
\hline & Cost leadership & Differentiation & Cost focus & Differentiation focus \\
\hline Product development & $\begin{array}{l}\text { Lower material inputs, ease of } \\
\text { manufacture; improve logistics }\end{array}$ & $\begin{array}{l}\text { Enhance quality and features; } \\
\text { deliverability }\end{array}$ & Minimum features & Niche market \\
\hline Process development & Learning curve; economies of scale & Precision; quality control; response time & Minimize cost & $\begin{array}{l}\text { Precision; quality } \\
\text { control; response time }\end{array}$ \\
\hline
\end{tabular}

promises to confer legitimacy or delay regulation ${ }^{6}$, (c) developing metaphors to create positive meanings and legitimacy for technologies (Geels and Verhees, 2011), e.g. 'clean coal', 'smart grids', 'low-carbon nuclear power'.

4. In response to normative pressures from civil society, firmsin-industries may use 'corporate social responsibility' (CSR) strategies, which can consist of corporate philanthropy (such as providing help for local nonprofit organizations or making donations in areas such as the arts, education, or social welfare) or 'doing the right thing' aimed at building goodwill and risk management (e.g. firms buying fair trade coffee or 'green electricity', or installing solar-panels to signal commitment to sustainability). Porter and Kramer (2011) make a plea for a 'creating shared value' (CSV) approach to CSR in which firms do not treat societal problems as peripheral matters, but as opportunities for value creation, e.g. by reconceiving products and markets (e.g. healthier products that offer better nutrition and address obesity problems) or redefining productivity in the value chain. They suggest that CSV may form the next stage in the evolution of capitalism, in which firms "take the lead in bringing business and society back together" (p. 64) and play active roles in addressing societal problems. They also note, however, that "we still lack an overall framework for guiding these efforts" (p. 64).

Firms-in-industries may also face normative pressures about specific social problems related to their performance, e.g. environmental issues (climate change with regard to cars, coal, oil), ethical issues (drug testing in animals), health issues (smoking, alcohol), or labour issues (e.g. Nike's sweatshops). Complaints and criticisms are often first articulated by activists or disadvantaged groups (Lounsbury et al., 2003; Elzen et al., 2011). In response, firms-in-industries may use issue management strategies (Mahon and Waddock, 1992; Zyglidopoulos, 2003), which aim to manage or contain criticisms. Initially, when activist groups are small, scattered and relatively powerless, firms-in-industries tend to reject or downplay their demands: "Corporations can easily ignore demands by a small number of 'fringe' activists whose views are not widely shared and who are without power" (Rivoli and Waddock, 2011: p. 90). But when critical groups become more organized and succeed in attracting public attention, their complaints may begin to affect firms' secondary involvement arenas (areas that affect companies, but are not central to its mission), in response to which firms often engage in political resistance activities or 'symbolic action' which "involves attempts to 'frame' an issue" (Mahon and Waddock, 1992: p. 27). When problems begin to affect primary involvement arenas (in the form of reputational damage, threat of regulation, consumer demand), firms tend to engage in 'substantive action' which "demands the expenditure of resources (money, equipment, personnel, etc.)" (Mahon and Waddock, 1992: p. 27). While substantive action may be oriented towards addressing the particular problem, firms may also employ it for

\footnotetext{
${ }^{6}$ The car industry, for instance, has promised 'green cars' since the 1990s to signal willingness to address climate change and argue that 'regulations are not needed, because we are working on solutions'. In 1990, General Motors promised that it would mass-market battery-electric vehicles by 1996. In 1997, Daimler-Benz promised it would start selling fuel cell vehicles in 2004 (Luger, 2000).
}

more defensive reasons. In an analysis of climate change activities of Financial Times Global 500 firms, Kolk and Pinkse (2007) found that many firms used voluntary initiatives with NGOs, government agencies or business consortia as more subtle ways to protect their interests, aimed at pre-empting negative effects of not dealing with the issue, forestalling future regulations, or opposing demands from more radical activist or interest groups. Innovation projects and change initiatives can thus be used for political or normative purposes.

\subsection{Strategic reorientation in response to external pressures}

The previous section discussed externally-oriented strategies that aim to position and/or defend firms-in-industries against environmental pressures (i.e. the 'horizontal' arrows in Fig. 1). Internally-oriented strategy approaches, on the other hand, address how firms can adapt to environmental pressures by changing core characteristics, e.g. routines, capabilities, belief system, mission (i.e. the 'vertical' dotted lines in Fig. 1 ). ${ }^{7}$ To conceptualize strategic reorientation in response to external pressures, I draw on two internally-oriented strategy approaches. The first approach, which clusters around (dynamic) capabilities, knowledge, and resources (Barney, 1991; Teece et al., 1997), highlights behavioural (trial-anderror) learning processes, in which problems trigger local search processes that produce incremental variations to which markets provide performance feedback. The second approach (Weick, 1995; Tripsas and Gavetti, 2000) highlights sense-making and cognitive learning processes, in which interpretations evolve gradually over time in relation to activities and feedback processes from environments (Child, 1997).

Although these approaches have different backgrounds, Demers (2007: p. 132) identifies a "convergence between the behavioural and cognitive learning approaches", arguing that "cognition and action are in an interactive relationship and cannot be divorced from each other" (p. 131). Other scholars (Tripsas and Gavetti, 2000; Gavetti et al., 2007; Nelson, 2008) also explore crossovers between both approaches for various reasons. One reason is that routine-based behavioural theory, which underlies the capability literature, pays little attention to intentional strategy and cognition (see the critical evaluation in Section 2.1). The concept of dynamic capabilities does not really solve this problem, because it refers to second-order routines, i.e. routines to change first-order routines (Winter, 2003). Furthermore, strategy not only depends on having dynamic capabilities, but also on using them appropriately, which highlights the importance of interpretative imagination

\footnotetext{
7 This framing of the phenomenon implies a focus on a particular kind of strategic reorientation, which is enacted in response to external pressures and performance problems and aims at restoring the fit with broader environments. This differs from another kind of strategic reorientation, based on the endogenous creation and exploitation of technological and market opportunities (which is often highlighted in innovation management and entrepreneurship schools). The reason for this focus relates to the paper's first motivation (industry reorientation in relation to grand challenges), which entails the accumulation of external pressures on firmsin-industries. Technological opportunities still play a role in this kind of strategic reorientation (to create options towards which firms can reorient), but their creation and exploitation follows accumulating pressures from external environments (happening in phase 3 in the phase-model discussed below).
} 
and creativity (Pandza and Thorpe, 2009). Another reason is that 'search' and 'performance feedback', which are core concepts in behavioural and capability approaches, tends to be operationalized in abstract non-cognitive ways (Gavetti et al., 2007). The interpretive strategy school can address these problems, firstly, by conceptualizing search and resource allocation as guided by strategic intent, interpretations and mental models (Child, 1997), and, secondly, by conceptualizing performance feedback from environments as involving interpretation and sensemaking (Weick, 1995; Hoffman and Ocasio, 2001).

Against this background, this section aims to develop a mixed behavioural-cognitive perspective on strategic reorientation. From the behavioural learning perspective it takes the importance of increasing economic pressures (e.g. changing markets, new entrants, supply pressures), political pressures (e.g. changing agendas or regulations), cultural pressures (e.g. changing cultural ideologies and discourses), and normative pressures (e.g. changing moral expectations or issue-related activist pressure). These pressures weaken performance in a broad sense, i.e. not only economic-financial performance as in behavioural theory of the firm, but also social fitness and legitimacy. Performance problems, in turn, trigger search processes for solutions, initially via 'local search' and subsequently via 'distant search'. From the sense-making perspective, the perspective accommodates the importance of interpreting signals from environments and the role of beliefs, mental maps, and strategic visions in guiding search processes. Expanding on Grinyer and McKiernan (1990), I propose that strategic reorientation progresses through four stages in which increasing pressures and performance problems stimulate actors to overcome lock-in mechanisms and question increasingly more foundational regime elements.

In the first stage, firms often deny or downplay problems arising from external pressures (Ford and Baucus, 1987). Actors may interpret problems as temporary (e.g. related to an economic recession or media-attention cycle) rather than permanent, and therefore take no action. Mis-interpretations may also be due to stubbornness, overconfidence, complacency, or reluctance to admit mistakes (Sutton, 1990).

In the second stage, when problems can no longer be denied, firms engage in local search that stays close to existing regime elements (Cyert and March, 1963). If problems are perceived to be related to operational issues, firms employ 'retrenchment strategies' such as downsizing, cost-cutting, efficiency improvements and tighter controls (Barker and Duhaime, 1997). They may also develop incremental technical innovations, make 'symbolic' changes in mission statements, or express concerns about specific issues (without engaging in much 'substantive' action). Peripheral firms or new entrants, which are less constrained by industry regimes, may start exploring more radical technical solutions to (societal) problems.

In the third stage, firms perceive performance problems as structural rather than temporary or operational. In this phase, "the search for solutions widens to more strategic changes, which involve changes in the disposition of resources, in the range of products, and in the markets served" (Grinyer and McKiernan, 1990: p. 134). Firms shift from 'local search' to 'distant search', and from the exploitation of existing technologies to the exploration of new knowledge bases and more radical alternatives (March, 1991). Core firms may enter into collaborations with peripheral firms or new entrants if these have developed relevant technical knowledge. Technological exploration, distant search and/or collaboration are guided by 'strategic intent' (Tidd et al., 2005) and visions. Subsequent strategic commitment and reorientation to new technologies, which are risky and uncertain processes, often entail a mix of external and internal processes. On the one hand, environmental jolts (Meyer et al., 1990) and the accumulation of stresses (Huff et al., 1992) may act as external trigger events to overcome lock-in mechanisms. On the other hand, the perception and endogenous creation of technological and market opportunities may lead to strategic maneuvering, abandoning of closed industry fronts and jockeying for position. Firms with faster and more appropriate interpretations and decisions may gain first mover advantages.

In the fourth stage, the continuation of problems stimulates firms to examine deep-structural elements such as core beliefs, mission and identity (Grinyer and McKiernan, 1990). This questioning of taken-for-granted practices and assumptions entails second-order cognitive learning (Argyris, 1982), which may be triggered by unfamiliar events (Barr, 1998) or external cultural pressures. $^{8}$ The 'unfreezing' or 'unlearning' of existing beliefs (Starbuck and Nystrom, 1984) creates space for a foundational rethink of the company, including business models, market positions, core competencies, and values. ${ }^{9}$

Fig. 2 provides a schematic summary of the stages and core processes in strategic reorientation, in which actors gradually question more foundational regime elements in response to external pressures and performance problems.

Fig. 2 suggests that core beliefs and missions are more difficult to change than technology and capabilities, which is why Tushman and Romanelli (1985) distinguish between 'strategic reorientation' (substantial changes in technology and marketing strategy) and 'strategic recreation' (which additionally entails changes in core beliefs and values).

\subsection{Positioning different strategies in the TEF}

The previous sections have discussed many different kinds of strategies, some of which were oriented externally towards different environments (Section 3.1), while others were more oriented towards internal adjustments in core characteristics (Section 3.2). This section tentatively identifies relations between strategies by positioning them in an adjusted version of Fig. 1, which now focuses on strategies rather than environmental pressures.

The basic idea is that the external (economic, political, cultural, and normative) strategies towards industry environments (Section 3.1) are accompanied by and embedded in processes of cognitive interpretation and sense-making (Weick, 1995). Pressures and signals from environments (e.g. consumer feedback, political discussions, public debates, activist claims) need to be picked up and interpreted (Hoffman and Ocasio, 2001). Furthermore, strategic decisions are themselves informed and influenced by belief systems and mental maps (Gavetti and Rivkin, 2007). Child (1997: p. 70) therefore proposes to see strategic choice as embedded in the following loop:

information from environment $\rightarrow$ evaluation $\rightarrow$ learning $\rightarrow$ strategic choice $\rightarrow$ action $\rightarrow$ outcome (effect in environment) $\rightarrow$ feedback of information from environment

By combining this loop with the multi-dimensionality of the TEF, it is possible to link various strategies. To that end, the 'loop'-idea should be elaborated as follows:

\footnotetext{
${ }^{8}$ In a case study of the American car industry, Penna and Geels (2012) showed that the 'Detroit mindset' (which assumed that 'what was good for the car industry was good for the country') had to adjust to cultural pressures in the 1970s, linked to rising environmentalism, an emerging activist culture, and public concerns about air pollution and car safety.

9 An example would be the redefinition of oil companies as energy companies, a notion that BP played with since the 1990s, but subsequently dropped. Another example would be a redefinition of car companies as mobility service provider, an idea that Daimler has started exploring in 2013 as it moved into the car sharing business.
} 


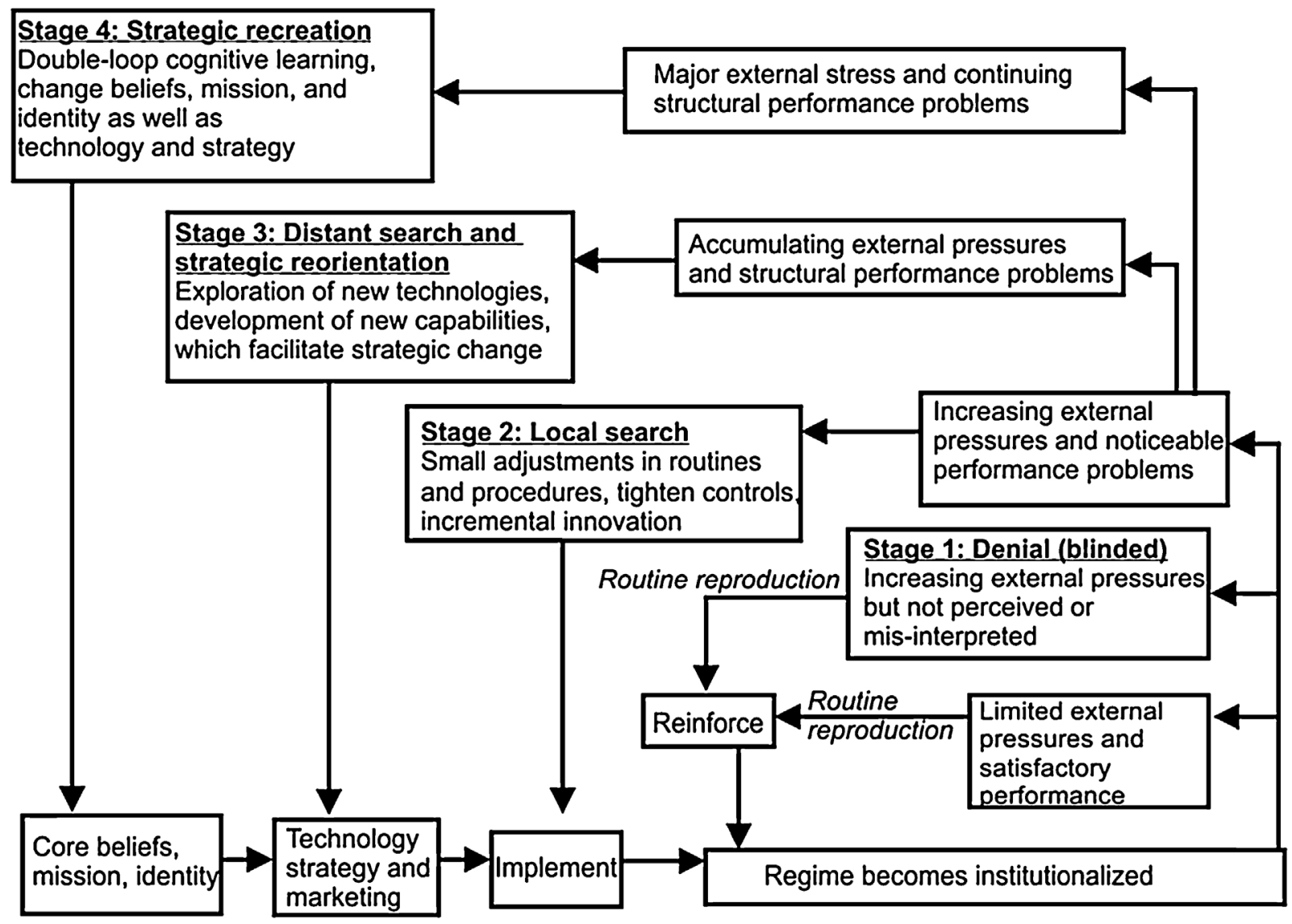

Fig. 2. Dynamics of strategic reorientation.

Substantially adapted from Grinyer and McKiernan (1990: p. 135).

- There is not one loop, but various loops towards different environments. This means that the 'action' term can be replaced with the more specific strategies, discussed in Section 3.1.

- 'Strategic choice', 'evaluation' and 'learning' are firm-internal processes which are integrative in the sense that they link the different loops: firms evaluate, weigh, rank and organize information from different environments and weave them into comprehensive stories (Pandza and Thorpe, 2009).

- 'Strategic choice' and 'evaluation' draw on various regime elements: (1) technical knowledge and capabilities shape perceptions of what is strategically possible ${ }^{10}$, (2) strategic thinking and evaluation draws on industry mindsets and cultural-cognitive institutions, which provide the categories, abstractions and typifications actors use in interpretation (Weber and Glynn, 2006), (3) industry regulations and governance mechanisms shape interpretation as to what is formally allowed, (4) a sense of identity "filters and models an organization's interpretation of and action on an issue" (Dutton and Dukerich, 1991: p. 520).

- 'Learning' provides a link between strategies in Sections 3.1 and 3.2, because experiences and feedbacks from various environments may lead actors to engage in behavioural and/or cognitive learning, which either leads to small adjustments (first-order learning) or larger changes (second-order or distant learning) in the case of substantial environmental pressure or weakening performance.

\footnotetext{
10 This is colloquially captured by the aphorism that 'when you have a hammer, everything looks like a nail'.
}

Fig. 3 aims to capture these relations in a stylized form, positioned in a TEF-representation.

\section{Implications for grand challenges}

The triple embeddedness framework (TEF), developed in Sections 2 and 3, provides a multi-dimensional conceptualisation of bi-directional interactions between firms-in-industries and their environments. With regard to the new agenda of grand societal challenges and reorientation of incumbent firms-in-industries, the TEF can be used to develop three guiding notions (Penna and Geels, 2012; Geels and Penna, 2013).

\subsection{External pressures from economic and socio-political environments}

Strategic reorientation of firms-in-an-industry requires increasing pressures from economic (task) and socio-political environments. Awareness of societal problems alone is insufficient, and without external pressures firms-in-industries are likely to remain locked-in to existing industry regimes. Building on issue lifecycle theory (Mahon and Waddock, 1992; Rivoli and Waddock, 2011), Penna and Geels (2012) suggest that pressures with regard to social issues increase along a regular pattern: (1) affected groups and activists first articulate complaints and criticisms about a problem, (2) concerns then spill over to public opinion and debates, (3) policymakers engage in debates (investigations, committees, hearings), (4) policymakers introduce substantive legislation to address the problem (changing taxes and economic frame 


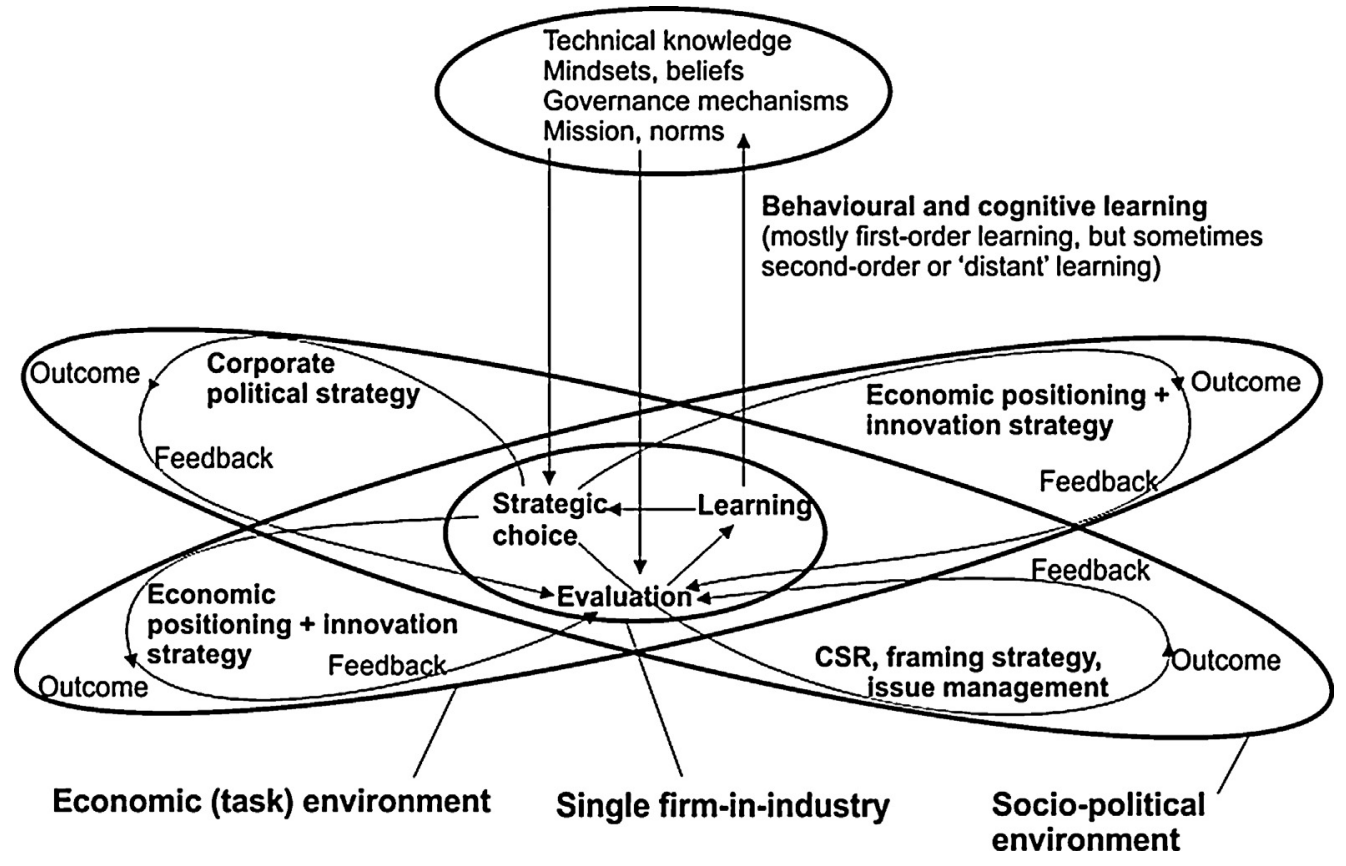

Fig. 3. Positioning different kinds of strategies in the triple embeddedness framework.

conditions), (5) markets change because of legislation or changing consumer preferences (when public debates are internalised into new behavioural norms). So, in terms of the TEF, pressures first emerge in the socio-political environment (1-3) and then spill over to the task environment (4-5).

Penna and Geels (2012) confirmed this general pattern in a longitudinal case study of local air pollution and the American car industry: (1) citizens in Los Angeles complained about smog in letters to newspapers (1943-1953), (2) anti-smog groups were formed (e.g. Stamp Out Smog) which raised the problem's public profile (1953-1960), (3) policymakers in California, where smog was experienced most prominently, debated the issue and introduced the first (weak) regulation, e.g. the Motor Vehicle Pollution Control Act (1960); federal policymakers organised National Conferences on Air Pollution (first one in 1958) and debated the need for national standards (1960-1970), (4) tough regulation (1970 Clean Air Act) was introduced in the context of wider social and cultural change (See footnote 8); American automakers resisted implementation of the CAA, which specified emissions standards with major reductions in nitrogen-oxide, hydro-carbons and carbon-monoxide (1970-1977); (5) policymakers relaxed and postponed standards until the early 1980 s, by which time automakers had developed three-way catalysts (1977-1985).

Although the case had a good fit with the proposed conceptual pattern, Penna and Geels (2012) also identified some deviations, particularly in the two later periods. First, American automakers engaged in successful political fight-back in the fourth period, which hindered regulatory implementation. Second, the problem of air pollution did not spill over to consumer demand in the fifth period. Third, the study showed that problem-related pressures can also decrease, which diminishes the public sense of urgency and political will to address the problem. Public opinion, for instance, became less concerned about air pollution from the mid-1970s onwards, because of other concerns (oil crises, fuel efficiency, recession). Fourth, American automakers strategically used their economic problems in the fifth period (when Japanese competition and a recession caused major financial problems) to argue successfully for various regulatory rollbacks. Penna and Geels (2012) therefore conclude that the analysis of societal problems should not only investigate problem-related pressures, but also other social and economic problems in the institutional and economic environments. The TEF offers an appropriate framework for investigating the wide range of environmental pressures faced by firms-in-industries, their ups and downs, and possible interactions.

\subsection{Response strategies towards external pressures}

Firms-in-industries are likely to resist external pressures for substantial reorientation, especially in the early phases of issue lifecycles. To defend their interests and sunk investments, they can use the whole spectrum of strategies discussed in Section 3.1 to delay or defuse social debates or political regulations.

In their case study of air pollution, Penna and Geels (2012) found that American automakers denied that cars caused smog problems in the first period, pointing instead to manufacturing and industrial districts as the principal offenders. In the second period, automakers argued that the scientific understanding of air pollution was too uncertain to assign blame and that LA was a special case because of topographical and meteorological conditions. Automakers also formed (1953) the Vehicle Combustion Products Committee, which not only created a closed industry front to defend their interests, but also entailed a secret agreement that firms would not compete in emission-control technologies. The industry also argued that regulations were not needed, because firms were already working on (incremental) solutions such as Positive Crankcase Ventilation (PCV). In the third period, when policymakers began considering regulations, automakers 'voluntarily' implemented PCV-devices, but also complained about high costs of pollution control technologies. They publicly rejected catalytic devices offered by suppliers from the chemical industry ('unfeasible', 'too expensive'), but privately initiated $R \& D$ programs to investigate the technology and build new capabilities. In 1969, an anti-trust case exposed the industry's conspiracy to delay pollution-control innovation, which caused public outrage that damaged its legitimacy and enhanced the willingness of policymakers to introduce tough legislation. 
In the fourth period, political strategies focused on fighting the 1970 Clean Air Act. CEOs spoke with President Nixon and lobbied senators and representatives. Firm representatives spoke at bi-annual hearings arguing that the technology was not available to meet the standards and that costs would be prohibitive. Ford started a 'grassroots' campaign to influence public opinion and mobilize communities to contact their political representatives. Chrysler published newspaper ads and a booklet stating that it would oppose CAA standards because they were "wasteful, unnecessary and unrealistic". Despite external resistance strategies, firms also stepped up their internal innovation efforts, moving gradually from incremental innovations to catalytic converters, which required new capabilities in chemistry and electronic controls. In the fifth period, automakers continued political strategies to relax and delay CAA standards: they refused to comply with 1978 standards (daring politicians to shut down factories) and mobilized supporters inside Congress to delay bills in hearings. By 1981, however, they introduced three-way catalytic converters, because they had acquired relevant technical capabilities and learned that electronic controls developed for TWC could also be used for general engine improvements.

This example not only shows that American automakers used various strategies to resist and delay addressing the particular problem, but also that the relative importance of strategies shifted from discursive strategies in early phases (to shape both public and political debates) to political resistance and innovation strategies in later phases. It also shows that innovation strategies were shaped by broader corporate strategies and social, economic, political and cultural contexts. And it shows how firms created a closed industry front in the early 1950s, which began to crack in the late 1960s and early 1970 s as a result of variation in firm-level technical strategies (see also below about GM's surprise reorientation towards catalytic converters).

\subsection{Reluctant and gradual reorientation}

In later stages of issue lifecycles, firms-in-industries may adjust core elements of industry regimes through 'strategic reorientation' (which changes technological capabilities and marketing strategy) or 'strategic recreation' (which additionally entails changes in core beliefs, identity and mission). As indicated in Section 3.2, these processes often entail not only accumulating external pressures around a social problem and spillovers to economic task environments but also the perception and creation of opportunities which may give rise to strategic manoeuvring and jockeying for position, which can accelerate reorientation. Geels and Penna (2013) emphasize the importance of economic and strategic opportunities, arguing that firms will rarely reorient merely to solve societal problems.

In their case study of air pollution, Penna and Geels (2012) found that technological reorientation of American automakers in the fourth period (1970-1977) was stimulated, on the one hand, by weakening performance (social and political legitimacy pressures) and, on the other hand, by GM, which in 1973 abandoned the industry position that catalytic converters were too expensive and announced that it would install them in 1975MY cars. With this surprise move, GM hoped to gain competitive advantage by using its patents to create barriers, by selling licenses, and by exploiting its investments in South African platinum mines (platinum being a core element of catalytic converters). Penna and Geels (2012) also showed that American automakers did not include the air pollution problem in their core beliefs or mission, because the problem did not affect consumer preferences and because it was seen as externally imposed by regulators, which led to culture of resistance on environmental matters.
In a longitudinal case study of auto-safety (1900-1995), Geels and Penna (2013) found that American automakers also engaged in reluctant technological reorientation (seatbelts, head restraints, energy-absorbing steering columns) after the tough 1966 National Traffic and Motor Vehicle Safety Act, complemented with political resistance strategies. But from the mid-1980s, when safety concerns began to affect consumer preferences, automakers abandoned the belief that 'safety does not sell', included safety in their mission and corporate strategies, and aggressively developed airbags and new capabilities in micro-electronics and digital technologies. This shift was partly triggered by Mercedes, which offered optional airbags in 1984MY cars. Positive attention from media and consumers stimulated other firms follow suit, leading to an airbag innovation race and escalating safety-patenting.

In a longitudinal case study of the UK coal industry (1913-1967), which also used the TEF as orienting framework, Turnheim and Geels (2013) found that industry actors resisted substantial changes in industry regimes for several decades, despite increasing external economic pressures (from substitutes such as coal gas and electricity, foreign mines and international coal, changing markets), cultural pressures (from discourses that framed coal as old-fashioned, dirty, inconvenient), normative pressures (from anti-smoke movements whose criticisms gained salience after the 1952 Great London Smog, which caused over 4000 excess deaths) and political pressures (from debates about a 'sick industry' which was slow to modernize and from dissatisfaction about 'featherbedding' and subsidies). In the 1946-1956 period, industry actors engaged in some technological reorientation in mining (coal-cutting machines, power loaders, underground locomotive haulage) and smokeless fuels (coke, briquettes), which required new chemical and thermal engineering capabilities. But it was not until they were overwhelmed by pressures in the 1956-1967 period that industry actors abandoned core beliefs (that coal was and would remain Britain's primary fuel) and mission (that coal was a supply-side industry that would always have many markets such as households, industry, railroads, shipping, electricity). In the early 1960s, industry actors accepted that coal was one fuel amongst others (oil, gas, nuclear), focused its mission towards the electricity supply industry, and rationalized to improve efficiency. Turnheim and Geels (2013) draw a conclusion that also applies to the other two cases summarised above: "mindsets, mission and identity were regime elements with the highest degree of lock-in. These elements are fundamental and constitutive, shaping 'ways of being' for industry actors. Technological and regulatory regime elements relate to 'ways of doing things', which were comparatively easier to change."

\section{Conclusions and discussion}

This paper has conceptually developed and elaborated a new triple embeddedness framework (TEF) to make two contributions to innovation studies. First, the TEF can be used to address the new agenda of grand societal challenges and the role of incumbent firms-in-industries. Section 4 suggested that substantial industry reorientation to address societal problems involves: (a) increasing problem-related pressures from institutional and economic environments, (b) industry fight-back and resistance to external pressures, (c) gradual reorientation of regime elements, based on technological search activities and cognitive adjustments in core beliefs and mission.

Second, the TEF offers a response to calls in the literature for frameworks that provide not only a broad understanding of co-evolution of industries and their environments but also conceptualise specific causal mechanisms (Malerba, 2006). This contribution aimed to enrich innovation studies theories (e.g. 
evolutionary economics, innovation management) with insights from wider social science theories (e.g. neo-institutional theory, economic sociology, strategy, organization theory). These crossovers resulted in multi-dimensional framework, which encompasses both context (selection pressures on industrial populations) and action (strategic firm-level responses). Action was conceptualized as both intentional (strategic, goal-oriented) and mediated (constrained and enabled by institutions). The TEF also encompasses both material dimensions (competition, resources, markets, technology) and ideational dimensions (normative and cultural pressures, sense-making, interpretations). Empirical studies based on outline versions of the TEF (Penna and Geels, 2012; Geels and Penna, 2013; Turnheim and Geels, 2013) also suggest that the framework goes a long way in meeting the criteria that Lewin and Volberda (1999) advanced for co-evolutionary frameworks (multilevelness/embeddedness, multidirectional causalities, nonlinearity, positive feedback, and path and history dependence). Although this has not been explicitly pursued in the paper, the TEF may also have relevance in relation to debates about multilevel selection (with environments exerting selection pressures on industries, which themselves form selection environments for firms).

As indicated in the introduction, the TEF is best seen as a framework rather than a theory. It aims to unravel the complexity of the co-evolution of industries and their environments by distinguishing: (a) various mechanisms through which (actors in) different environments exert pressures on firms-in-industries, (b) various strategies firms can use in response to these pressures, and (c) various regime elements which enable and constrain the perceptions and strategies of firms-in-industries. So, the TEF aims to combine and position a collection of processes and causal mechanisms in relation to each other. For different industries, countries and societal problems these mechanisms may combine into different patterns, depending on: (a) the strength, directionality and interactions between external pressures, (b) the kinds of firm-level response strategies and interpretive processes, and (c) the strength of regime level lock-in mechanisms. So, the TEF aims to inspire rich, longitudinal, and multi-dimensional empirical research. Even though each case study may have unique characteristics, it is expected that different outcomes can be explained by varying combinations of similar mechanisms, which thus enables comparison and generalization within a versatile framework.

The TEF was developed with certain industries in mind, e.g. oil, coal, automobiles, electric utilities, gas, agrofood. Many of these industries are associated with societal problems (e.g. climate change, obesity) and incumbent firms show reluctance to address them. These industries also have strong political influences and high public visibility, which is why the TEF includes political, cultural, and normative processes. This also means that aspects of the TEF may be more back-grounded for analyses of industries which nowadays have less explicit political and sociocultural dimensions (e.g. furniture, machine-tools, instruments, glass). Another limitation is the trade-off between depth and breadth. Although my characterization of theories aimed to do justice to core ideas, the discussion could not cover the various nuances and varieties in each field. Furthermore, several aspects have not been addressed. The TEF does not include psychological and biological approaches to cognition (how the mind works) with an individualistic orientation. It also does not address what goes on inside firms, which would introduce another layer of complexity (on top of the current layers of environments, industry, and firms). Future work could also broaden the conceptualisation of industries and include the roles of labour unions, shareholders, test agencies, standardisation organizations, and distribution chains.

\section{Acknowledgements}

I want to thank Caetano Penna and Bruno Turnheim for several rounds of thoughtful feedback on previous versions of the paper. I also want to thank Mike Hobday, Ed Steinmueller, Ben Martin, Jeroen van den Bergh, Fred Steward, Florian Kern, Staffan Jacobsson, Andy McMeekin, Ulrich Dolata, Gerhard Fuchs, and three anonymous reviewers for their stimulating comments. This work has been supported by an ERC grant (No. 204246).

\section{References}

Aldrich, H.E., 2010. Beam me up, Scott(ie)! Institutional theorists' struggles with the emergent nature of entrepreneurship. Research in the Sociology of Work 20, 329-364.

Andersen, E.S., 2009. Schumpeter's Evolutionary Economics: A Theoretical, Historical and Statistical Analysis of the Engine of Capitalism. Anthem Press, London, UK.

Argyris, C., 1982. The executive mind and double loop learning. Organizational Dynamics 11 (2), 5-22.

Arthur, W.B., 1989. Competing technologies, increasing returns, and lock-in by historical events. Economic Journal 99 (394), 116-131.

Astley, W.G., Van de Ven, A.H., 1983. Central perspectives and debates in organization theory. Administrative Science Quarterly 28 (2), 245-273.

Barker, V.L., Duhaime, I.M., 1997. Strategic change in the turnaround process: theory and empirical evidence. Strategic Management Journal 18 (1), 13-38.

Barley, S.R., 2010. Building an institutional field to corral a government: a case to set an agenda for organization studies. Organization Studies 31 (6), 777-805.

Barney, J.B., 1991. Firm resources and sustained competitive advantage. Journal of Management 17, 395-410.

Barr, P.S., 1998. Adapting to unfamiliar environmental events: a look at the evolution of interpretation and its role in strategic change. Organization Science 9 (6), $644-669$.

Blyth, M., 2002. Great Transformations: Economic Ideas and Institutional Change in the Twentieth Century. Cambridge University Press, New York.

Chaffee, E.E., 1985. Three models of strategy. Academy of Management Review 10 (1), 89-98.

Child, J., 1997. Strategic choice in the analysis of action, structure, organizations and environment: retrospect and prospect. Organization Studies 18 (1), 43-76.

Cyert, R.M., March, J.G., 1963. A Behavioral Theory of the Firm. Prentice Hall, Englewood Cliffs, NJ.

Daft, R., Weick, K., 1984. Toward a model of organizations as interpretation systems. Academy of Management Review 9 (2), 284-295.

Demers, 2007. Organizational Change Theories: A Synthesis. Sage Publications, London.

DiLorenzo, T.J., 1996. The myth of natural monopoly. The Review of Austrian Economics 9 (2), 43-58

DiMaggio, P.J., Powell, W.W., 1983. The iron cage revisited: institutional isomorphism and collective rationality in organizational fields. American Sociological Review 48 (2), 147-160.

Dobbin, F., 2004. The New Economic Sociology: A Reader. Princeton University Press, Princeton, NJ

Dosi, G., 1982. Technological paradigms and technological trajectories: a suggested interpretation of the determinants and directions of technical change. Research Policy 6 (3), 147-162.

Dosi, G., 2000. Innovation, Organization and Economic Dynamics. Edward Elgar, Cheltenham, UK.

Dosi, G., Grazzi, M., 2006. Technologies as problem-solving procedures and technologies as input-output relations: some perspectives on the theory of production. Industrial and Corporate Change 15 (1), 173-202.

Dosi, G., Marengo, L., 2007. On the evolutionary and behavioural theories of organizations: a tentative roadmap. Organization Science 18 (3), 491-502.

Douglas, M., 1986. How Institutions Think. Syracuse University Press, New York.

Dutton, J.E., Dukerich, J.M., 1991. Keeping an eye on the mirror: image and identity in organizational adaptation. Academy of Management Journal 34 (3), 517-554.

Edelman, L., Suchman, M., 1996. The legal environment of organizations. Annual Review of Sociology 23, 479-515.

Elzen, B., Geels, F.W., Leeuwis, C., Van Mierlo, B., 2011. Normative contestation in transitions 'in the making': animal welfare concerns and system innovation in pig husbandry (1970-2008). Research Policy 40 (2), 263-275.

Etzion, D., 2007. Research on organizations and the natural environment, 1992present: a review. Journal of Management 33 (4), 637-664.

Fagerberg, J., 2003. Schumpeter and the revival of evolutionary economics: an appraisal of the literature. Journal of Evolutionary Economics 13 (2), 125-159.

Flanagan, K., Uyarra, E., Laranja, M., 2011. Reconceptualising the 'policy mix' for innovation. Research Policy 40 (5), 702-713.

Fligstein, N., 1996. Markets as politics: a political-cultural approach to market institutions. American Sociological Review 61 (4), 656-673.

Fligstein, N., McAdam, D., 2012. A Theory of Fields. Oxford University Press, Oxford.

Fombrun, C., Shanley, M., 1990. What's in a name? Reputation building and corporate strategy. Academy of Management Journal 33 (2), 233-258. 
Ford, J.D., Baucus, D.A., 1987. Organizational adaptation to performance downturns: an interpretation-based perspective. Academy of Management Review 12 (2), 366-380.

Freeman, C., 1988. Preface to Part II: evolution, technology and institutions: a wider framework for economic analysis. In: Dosi, G., et, al. (Eds.), Technical Change and Economic Theory. Pinter, London, pp. 9-13.

Furrer, O., Thomas, H., Goussevskaia, A., 2008. The structure and evolution of the strategic management field: a content analysis of 26 years of strategic management research. International Journal of Management Reviews 10 (1), 1-23.

Garud, R., Hardy, C., Maguire, S., 2007. Institutional entrepreneurship as embedded agency: an introduction to the special issue. Organization Studies 28 (7), 957-969.

Gavetti, G., Levinthal, D., 2004. Strategy field from the perspective of management science: divergent strands and possible integration. Management Science 50 (10), 1309-1318

Gavetti, G., Levinthal, D., Ocasio, W., 2007. Neo-Carnegie: the Cargenie School's past, present, and reconstructing for the future. Organization Science 18 (3), 523-536.

Gavetti, G., Rivkin, J.W., 2007. On the origin of strategy: action and cognition over time. Organization Science 18 (3), 420-439.

Geels, F.W., Verhees, B., 2011. Cultural legitimacy and framing struggles in innovation journeys: a cultural-performative perspective and a case study of Dutch nuclear energy (1945-1986). Technological Forecasting \& Social Change 78 (6), 910-930.

Geels, F.W., Penna, C.C.R., 2013. Societal problems and industry reorientation: Elaborating the Dialectic Issue LifeCycle (DILC) model and a case study of car safety in the USA (1900-1995). Research Policy (under review).

Giddens, A., 1979. Central Problems in Social Theory: Action, Structure and Contradiction in Social Analysis. University of California Press, Berkely and Los Angeles.

Godoe, H., 2000. Innovation regimes, R\&D and radical innovations in telecommunications. Research Policy 29 (9), 1033-1046.

Granovetter, M., 1985. Economic action and social structure: the problem of embeddedness. American Journal of Sociology 91 (3), 481-510.

Grant, R., 1996. Toward a knowledge-based theory of the firm. Strategic Management Journal 17 (Winter special issue), 109-122.

Greenwood, R., Hinings, C.R., 1996. Understanding radical organizational change: bringing together the old and the new institutionalism. Academy of Management Review 21 (4), 1022-1054.

Greenwood, R., Suddaby, R., 2006. Institutional entrepreneurship in mature fields: the big five accounting firms. Academy of Management Journal 49 (1), 27-48.

Greve, H.R., 2003. Organizational Learning from Performance Feedback: A Behavioural Perspective on Innovation and Change. Cambridge University Press, Cambridge.

Grinyer, P., McKiernan, P., 1990. Generating major change in stagnating companies. Strategic Management Journal 11, 131-146.

Haveman, H.A., Rao, H., 1997. Structuring a theory of moral sentiments: institutional and organizational coevolution in the early thrift industry. American Journal of Sociology 102 (6), 1606-1651

Hillman, A., Hitt, M., 1999. Corporate political strategy formulation: a model of approach, participation, and strategy decisions. Academy of Management Review 24 (4), 825-842.

Hodgson, G.M., 1993. Economics and Evolution: Bringing Life Back into Economics. Polity Press, Cambridge.

Hoffman, A.J., Ocasio, W., 2001. Not all events are attended equally: toward a middle range theory of industry attention to external events. Organization Science 12 (4), 414-434.

Hoskisson, R.E., Hitt, M.A., Wan, W.P., Yiu, D., 1999. Theory and research in strategic management: swings of a pendulum. Journal of Management 25 (3), 417-456.

Huff, J.O., Huff, A.S., Thomas, H.T., 1992. Strategic renewal and interaction of cumulative stress and inertia. Strategic Management Journal 13 (Summer special issue), $55-75$

Jessop, B., 2010. Cultural political economy and critical policy studies. Critical Policy Studies 3 (3-4), 336-356.

Kolk, A., Pinkse, J., 2007. Multinationals' political activities on climate change. Business \& Society 46 (2), 201-228.

Krippner, G.R., 2001. The elusive market: embeddedness and the paradigm of economic sociology. Theory and Society 30 (6), 775-810.

Krippner, G., Granovetter, M., Block, F., Biggart, N., Beamish, T., Hsing, Y., Hart, G., Arrighi, G., Mendell, M., Hall, J., Burawoy, M., Vogel, S., O’Riain, S., 2004. Polanyi symposium: a conversation on embeddedness. Socio-Economic Review 2, 109-135.

Leblebici, H., Salancik, G.R., Copay, A., King, T., 1991. Institutional change and the transformation of interorganizational fields: an organizational history of the U.S. radio broadcasting industry. Administrative Science Quarterly 36 (3), 333-363.

Leonard-Barton, D., 1992. Core capabilities and core rigidities: a paradox in managing new product development. Strategic Management Journal 13 (Special issue), $111-125$.

Levinthal, D.A., 1991. Organizational adaptation and environmental selection: interrelated processes of change. Organization Science 2 (1), 140-145.

Levy, D.L., Egan, D., 2003. A neo-Gramscian approach to corporate political strategy: conflict and accommodation in the climate change negotiations. Journal of Management Studies 40 (4), 803-830.

Lewin, A.Y., Volberda, H.W., 1999. Prolegomena on co-evolution: a framework for research on strategy and new organizational forms. Organization Science 10 (5), 519-534.
Lewin, A.Y., Volberba, H.W., 2003. Beyond adaptation versus selection research: organizing self-renewal in co-evolving environments. Journal of Management Studies 40 (8), 2109-2110.

Lindblom, C.E., 2001. The Market System. What It Is, How It Works, and What To Make of It. Yale University Press, New Haven, CT.

Lounsbury, M., Glynn, M.A., 2001. Cultural entrepreneurship: stories, legitimacy, and the acquisition of resources. Strategic Management Journal 22 (6-7), 545-564.

Lounsbury, M., Ventresca, M., Hirsch, P.M., 2003. Social movements, field frames and industry emergence: a cultural-political perspective on US recycling. SocioEconomic Review 1 (1), 71-104.

Luger, S., 2000. Corporate Power, American Democracy, and the Automobile Industry. Cambridge University Press, Cambridge.

Lundvall, B.A. (Ed.), 1992. National Systems of Innovation: Towards a Theory of Innovation and Interactive Learning. Pinter Publishers, London.

Mahon, J.F., Waddock, S.A., 1992. Strategic issues management: an integration of issue life cycle perspectives. Business \& Society 31, 19-32.

Malerba, F., 2006. Innovation and the evolution of industries. Journal of Evolutionary Economics 16 (1), 3-23.

March, J.G., 1991. Exploration and exploitation in organizational learning. Organization Science 2 (1), 71-87.

Meyer, A.D., Brooks, G.R., Goes, J.B., 1990. Environmental jolts and industry revolutions: organizational responses to discontinuous change. Strategic Management Journal 11 (Summer special issue), 93-110.

Mintzberg, H., Ahlstrand, B., Lampel, J., 1998. Strategy Safari: A Guided Tour through the Wilds of Strategic Management. The Free Press, New York.

Morlacchi, P., Martin, B., 2009. Emerging challenges for science, technology and innovation policy research: a reflexive overview. Research Policy 38 (4), 571-582.

Nelson, R.R., Winter, S.G., 1982. An Evolutionary Theory of Economic Change. Belknap Press, Cambridge (Mass.).

Nelson, R.R. (Ed.), 1993. National Systems of Innovation: A Comparative Analysis Oxford University Press, Oxford.

Nelson, R.R., 1994. The co-evolution of technology, industrial structure, and supporting institutions. Industrial and Corporate Change 3 (1), 47-63.

Nelson, R.R., 2002. Bringing institutions into evolutionary growth theory. Journal of Evolutionary Economics 12 (1-2), 17-28.

Nelson, R.R., 2008. Bounded rationality, cognitive maps, and trial and error learning. Journal of Economic Behaviour \& Organization 67 (1), 78-89.

North, D.C., 1990. Institutions, Institutional Change and Economic Performance. Cambridge University Press, Cambridge.

North, D.C., 2005. Understanding the Process of Economic Change. Princeton University Press, Princeton, NJ.

Oliver, C., 1991. Strategic responses to institutional processes. Academy of Management Review 16 (1), 145-179.

Oliver, C., 1997. The influence of institutional and task environment relationships on organizational performance: the Canadian construction industry. Journal of Management Studies 34 (1), 99-124.

Pandza, K., Thorpe, R., 2009. Creative search and strategic sensemaking: missing dimensions in the concept of dynamic capabilities. British Journal of Management 20, S118-S131.

Parsons, T., 1937. The Structure of Social Action. McGraw-Hill, New York.

Pelikan, P., 2003. Bringing institutions into evolutionary economics: another view with links to changes on physical and social technologies. Journal of Evolutionary Economics 13, 237-258.

Penna, C.C.R., Geels, F.W., 2012. Multi-dimensional struggles in the greening of industry: a dialectic issue lifecycle model and case study. Technological Forecasting and Social Change 79 (6), 999-1020.

Pettigrew, A.M., 2012. Context and action in the transformation of firms: a reprise. Journal of Management Studies 49 (7), 1304-1328.

Phillips, M.E., 1994. Industry mindsets: exploring the cultures of two macroorganizational settings. Organization Science 5 (3), 384-402.

Polanyi, K., 1944. The Great Transformation: The Political and Economic Origins of Our Time. Beacon Press, Boston.

Porac, J.F., Thomas, H., Baden-Fuller, C., 1989. Competing groups as cognitive communities: the case of the Scottish knitwear manufacturers. Journal of Management Studies 26 (4), 397-416.

Porter, M., 1980. Competitive Strategy: Techniques for Analyzing Industries and Competitors. Free Press, New York.

Porter, M., 1991. Towards a dynamic theory of strategy. Strategic Management Journal 12 (Winter special issue), 95-117.

Porter, M., Kramer, M., 2011. Creating shared value: how to reinvent capitalism; and unleash a wave of innovation and growth. Harvard Business Review 89 (1-2), $62-77$.

Powell, W., 1991. Expanding the scope of institutional analysis. In: Powell, W. DiMaggio, P. (Eds.), The New Institutionalism in Organizational Analysis. University of Chicago Press, Chicago, pp. 183-203.

Powell, W., DiMaggio, P., 1991. The New Institutionalism in Organizational Analysis. University of Chicago Press, Chicago.

Rivoli, P., Waddock, S., 2011. "First they ignore you. ..": the time-context dynamic and corporate responsibility. California Management Review 53, 87-104

Robertson, P.L., Langlois, R.N., 1994. Institutions, inertia and changing industrial leadership. Industrial and Corporate Change 3 (2), 359-378.

Rothaermel, F., 2001. Incumbent's advantage through exploiting complementary assets via interfirm cooperation. Strategic Management Journal 22 (6-7) 687-699. 
Schot, J.W., Geels, F.W., 2007. Niches in evolutionary theories of technical change: a critical survey of the literature. Journal of Evolutionary Economics 17 (5), $605-622$.

Schumpeter, J.A., 1954. History of Economic Analysis. Oxford University Press, New York.

Scott, W.R., 1995. Institutions and Organizations. Sage publications, Thousand Oaks, CA.

Scott, W.R., 2001. Institutions and Organizations, second edition. Sage publications, Thousand Oaks, CA.

Scott, W.R., Ruef, M., Mendel, P.J., Caronna, C.A., 2000. Institutional Change and Healthcare Organizations. Chicago University Press, Chicago.

Scott, W.R., 2008. Approaching adulthood: the maturing of institutional theory. Theory and Society 37 (5), 427-442.

Snow, D.A., Benford, R., 1988. Ideology, frame resonance, and participant mobilization. International Social Movement Research 1, 197-217.

Spender, J.C., 1989. Industry Recipes and Enquiry into the Nature and Sources of Managerial Judgement. Basil Blackwell, Oxford.

Starbuck, W.H., Nystrom, P.C., 1984. To avoid organizational crises, unlearn. Organizational Dynamics 12 (4), 53-65.

Suchman, M.C., 1995. Managing legitimacy: strategic and institutional approaches. Academy of Management Review 20 (3), 571-611.

Sutton, R.I., 1990. Organizational decline processes: a social psychological perspective. Research in Organizational Behaviour 12, 205-253.

Teece, D.J., Pisano, G., Shuen, A., 1997. Dynamic capabilities and strategic management. Strategic Management Journal 18 (7), 509-533.

Tidd, J., Bessant, J., Pavitt, K., 2005. Managing Innovation: Integrating Technological, Market and Organizational Change, 3rd edition. John Wiley \& Sons Ltd, Chichester, England.

Tripsas, M., Gavetti, G., 2000. Capabilities, cognition and inertia: evidence from digital imaging. Strategic Management Journal 21 (10-11), 1147-1161.

Turnheim, B., Geels, F.W., 2013. The destabilisation of existing regimes: confronting a multi-dimensional framework with a case study of the British coal industry (1913-1967). Research Policy (forthcoming).
Tushman, M.L., Romanelli, E., 1985. Organizational evolution: a metamorphosis model of convergence and reorientation. In: Cummings, L.L., Staw, B.M. (Eds.), Research in Organizational Behavior, vol. 7. JAI Press, Greenwich, CT, pp. 171-222.

Tushman, M., Anderson, P., 1986. Technological discontinuities and organization environments. Administrative Science Quarterly 31 (3), 439-465.

Unruh, G.C., 2000. Understanding carbon lock-in. Energy Policy 28 (12), 817-830.

Von Tunzelman, N., 2003. Historical coevolution of governance and technology in the industrial revolutions. Structural Change and Economic Dynamics 14 (4), 565-384.

Walker, W., 2000. Entrapment in large technology systems: institutional commitments and power relations. Research Policy 29 (7-8), 833-846.

Weber, M., 1946. The social psychology of the world religions. In: Gerth, H.H., Wright Mills, C. (Eds.), From Max Weber. Oxford University Press, New York, pp. 267-301 (1922-1923)

Weber, K., Glynn, M.A., 2006. Making sense with institutions: context, thought and action in Karl Weick's theory. Organization Studies 27 (11), 1639-1660.

Weick, K.E., 1995. Sensemaking in Organizations. Sage Publications, Thousand Oaks, CA.

Winter, S.G., 2003. Understanding dynamic capabilities. Strategic Management Journal 24 (10), 991-995.

Yoffie, D., 1988. The politics of business: how an industry builds political advantage. Harvard Business Review 66 (3), 82-89.

Zilber, T.B., 2007. Stories and the discursive dynamics of institutional entrepreneurship: the case of Israeli high-tech after the bubble. Organization Studies 28 (7), 1035-1054.

Zyglidopoulos, S.C., 2003. The issue life-cycle: implications for reputation for social performance and organizational legitimacy. Corporate Reputation Review 6 (1), $70-81$.

Zucker, L.G., 1987. Institutional theories of organizations. Annual Review of Sociology 3, 443-464.

Zukin, S., DiMaggio, P. (Eds.), 1990. Structures of Capital: The Social Organization of the Economy. Cambridge University Press, Cambridge. 